Research Article

Cristiana Petrinelli Pannocchia*, Alice Vassanelli

\title{
The First Italian Farmers: The Role of Stone Ornaments in Tradition, Innovation, and Cultural Change
}

https://doi.org/10.1515/opar-2020-0175

received December 10, 2020; accepted June 20, 2021

\begin{abstract}
When the first farmers landed on the eastern coast of the Italian peninsula (end of seventh millennium cal $\mathrm{BC}$ ), they brought with them a system of knowledge and technologies that quickly spread along both the Tyrrhenian and Adriatic coasts. The study of the material culture, therefore, assumes an important role in understanding the social and cultural identity of these incoming groups. Analyses of ornament production - involving manufacture technology, raw materials, and stylistic choices - may supply information about the cultural choices and the technical skills of human groups and shed light on the social and symbolic system of these ancient populations. Data obtained from this work show that the ornaments became symbols of a growing cultural identity, which began to be developed within Italian territory. In the ornamental assemblages of the newcomers, the relevance of shaped lithic items is clearly visible, and there was the development of types that will become more and more standardized during the Neolithic period. However, elements in the symbolic culture of these first settlers, such as the use of Columbella rustica and the exclusive production of hard animal matter ornaments in some sites, recall previous traditions. This study intends to extend our knowledge on the ornamental customs of the first Italian Neolithic communities. It will attempt to establish if the chronological and the geographical differences that emerge from our analyses reflect diversities in the cultural and symbolic systems of the incoming farmers and different possible interactions with the native population.
\end{abstract}

Keywords: Early Neolithic, identity, Italy, stone beads, bracelet

\section{Introduction}

In Europe, the transition to farming was not a linear process (Manen et al., 2019; Shennan, Downey, \& Timpson, 2013), and in many regions, the question remains as to the relationship between the newcomers and the indigenous inhabitants.

The spread of the Neolithic culture throughout the Mediterranean area was facilitated by human groups that brought with them innovative technologies and new artifacts as part of the "Neolithic package."

Special Issue: THE EARLY NEOLITHIC OF EUROPE, edited by F. Borrell, I. Clemente, M. Cubas, J. J. Ibáñez, N. Mazzucco, A. Nieto-Espinet, M. Portillo, S. Valenzuela-Lamas, \& X. Terradas

\footnotetext{
* Corresponding author: Cristiana Petrinelli Pannocchia, Department of Civilisations and Forms of Knowledge, University of Pisa, Via dei Mille 19, 56126 Pisa, Italy, e-mail: cristiana.petrinelli@unipi.it

Alice Vassanelli: Department of Civilisations and Forms of Knowledge, University of Pisa, Via dei Mille 19, 56126 Pisa, Italy, e-mail: alice.vassanelli@cfs.unipi.it
} 
The passage from foraging to a production economy had an impact not only on different aspects of the daily life of the human groups but also on their symbolic codes.

When the first farmers reached the south-eastern coasts of the Italian peninsula (end of seven millennium cal BC), new systems of knowledge and technologies quickly spread along both coasts and then carried on through to the north.

As many authors claim, a holistic approach to the personal ornament production - involving manufacture technology, raw materials, and stylistic choices - supplies information about the cultural choices and the technical skills of human groups, but it can also shed light on the role these objects played in the social and symbolic system of the ancient populations (Vanhaeren \& D'Errico, 2006).

Data provided from the study of early Neolithic ornamental assemblage show the presence of new highly elaborated items and the progressive development of local customs and behavior patterns due to the progressive formation and stabilization of new communities (Pessina \& Tiné, 2008).

However, some elements reveal that these incoming farmers also adopted some features of the previous local traditions, such as the use of Columbella rustica and perforated teeth. The kind of interaction they had with the local hunter-gatherer communities, especially in the central-southern part of the Italian peninsula, remains a widely debated issue due to the scarcity of Late Mesolithic sites (Franco, 2011; Radi \& Petrinelli Pannocchia, 2018). Data do not allow for the exclusion that some elements were already part of the traditional heritage of the newcomers (Tozzi, 1996).

In Italy, detailed studies on the prehistoric personal body adornments to date has been focused on northern regions and on specific cultural groups (Bernabò Brea, Maffi, Mazzieri, \& Salvadei, 2010; Micheli, 2012) or raw materials (Borrello \& Micheli, 2005; Borrello \& Rossi, 2005), so that the picture we have remains very limited.

This article intends to review the evidence relating to the production of Neolithic personal ornaments relating to the whole Italian peninsula through the analyses of the main stone elements: pendants, shaped beads, and bracelets.

The evidence provided is collected from published sources, so it may not fully represent the actual composition of the Neolithic repertoire. Publications, especially the older ones, often omit the presence of ornaments in the sites or provide only a hint to their presence. Moreover, during the past excavations, their number could have been, at times, underestimated due to inadequate recovery techniques employed.

A brief overview of the pre-Neolithic ornamental assemblages is followed by an analysis about how and where new Neolithic stone ornaments spread in the Italian peninsula, underlining the eventual differences in their production and geographical distribution. To complete the picture of early Neolithic adornments customs, a synthesis of nonlithic items will also be presented.

The chronological and the geographical differences are examined to understand more fully if they reflect diversities in the cultural and symbolic systems of the incoming groups, as well as suggest potential interrelations among the newcomers and the native population.

\section{The Neolithization of Italy: A Brief Overview}

Guilaine (2018) remarked that "the early Neolithic of the Central Mediterranean is a real kaleidoscope and, beyond distinct common basic denominators, it exhibits strong ceramic and lithic variability". The framework at our disposal for the early Italian Neolithic period is continuously refined by new data (Biagi \& Starnini, 2021; Binder et al., 2017; Delpino, 2020). The first farmers arrived in south-eastern Italy (Apulia) around the end of seventh millennium cal BC (i.e., Pulo di Molfetta: LTL-142A $7130 \pm 60$ BP, Binder et al., 2017; Ripa Tetta: Beta-47808 $6988 \pm 45$ BP, Binder et al., 2017; Favella: LTL-778A $7003 \pm 55$ BP, Tiné, 2009; Table 1). They rapidly penetrated to the hinterland, into the Ionic area and along the Tyrrhenian coast, as shown by the impressed-ceramic levels discovered at the Arene Candide Cave (Beta-66553 $6880 \pm 60$ BP, Bernabò Brea, 1946, 1956; Binder \& Maggi, 2001; Maggi, 1997). The early Neolithic of southern Italy, in relation to the Impressed Ware groups, shows a regional variability in the morphological and decorative 


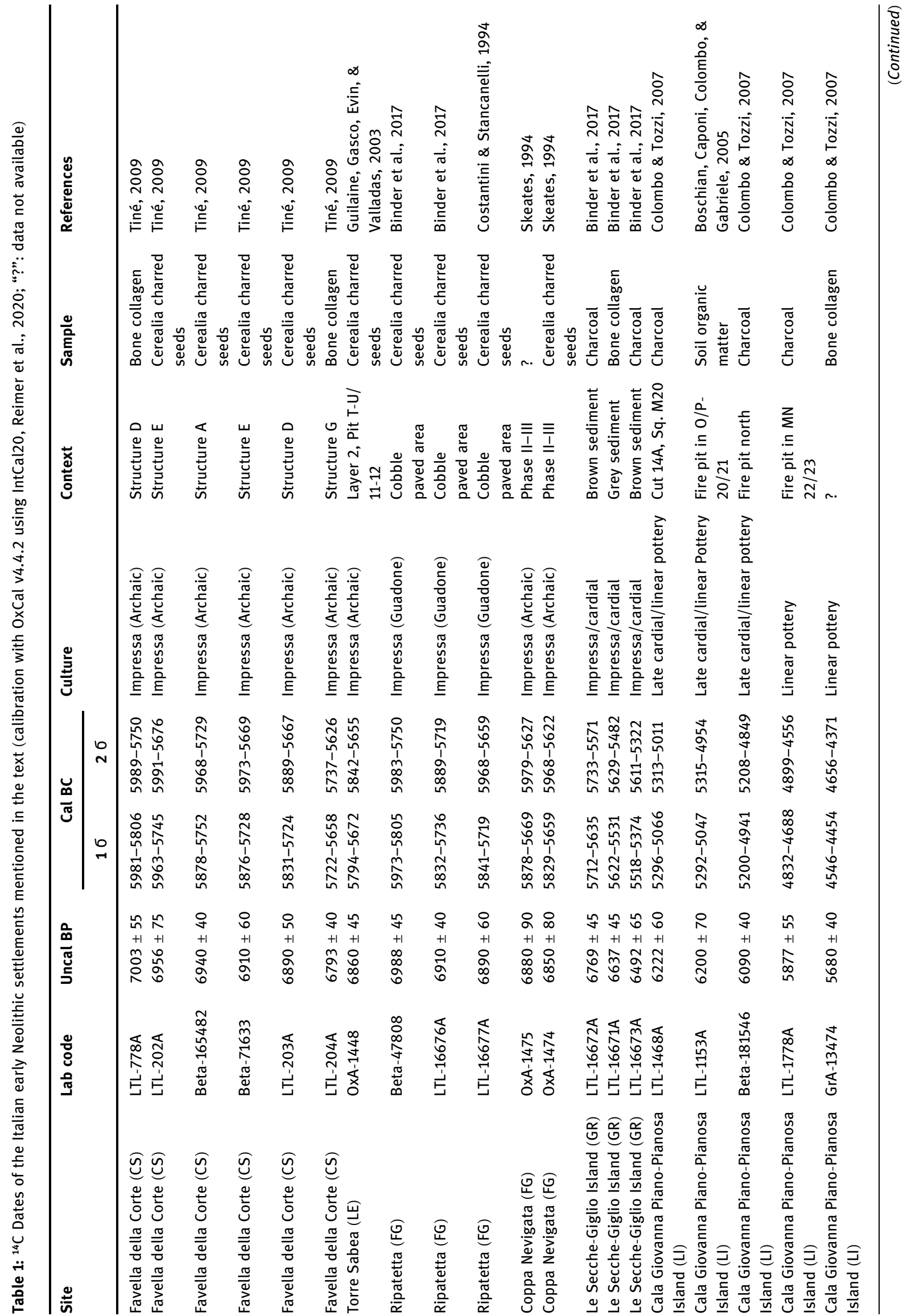




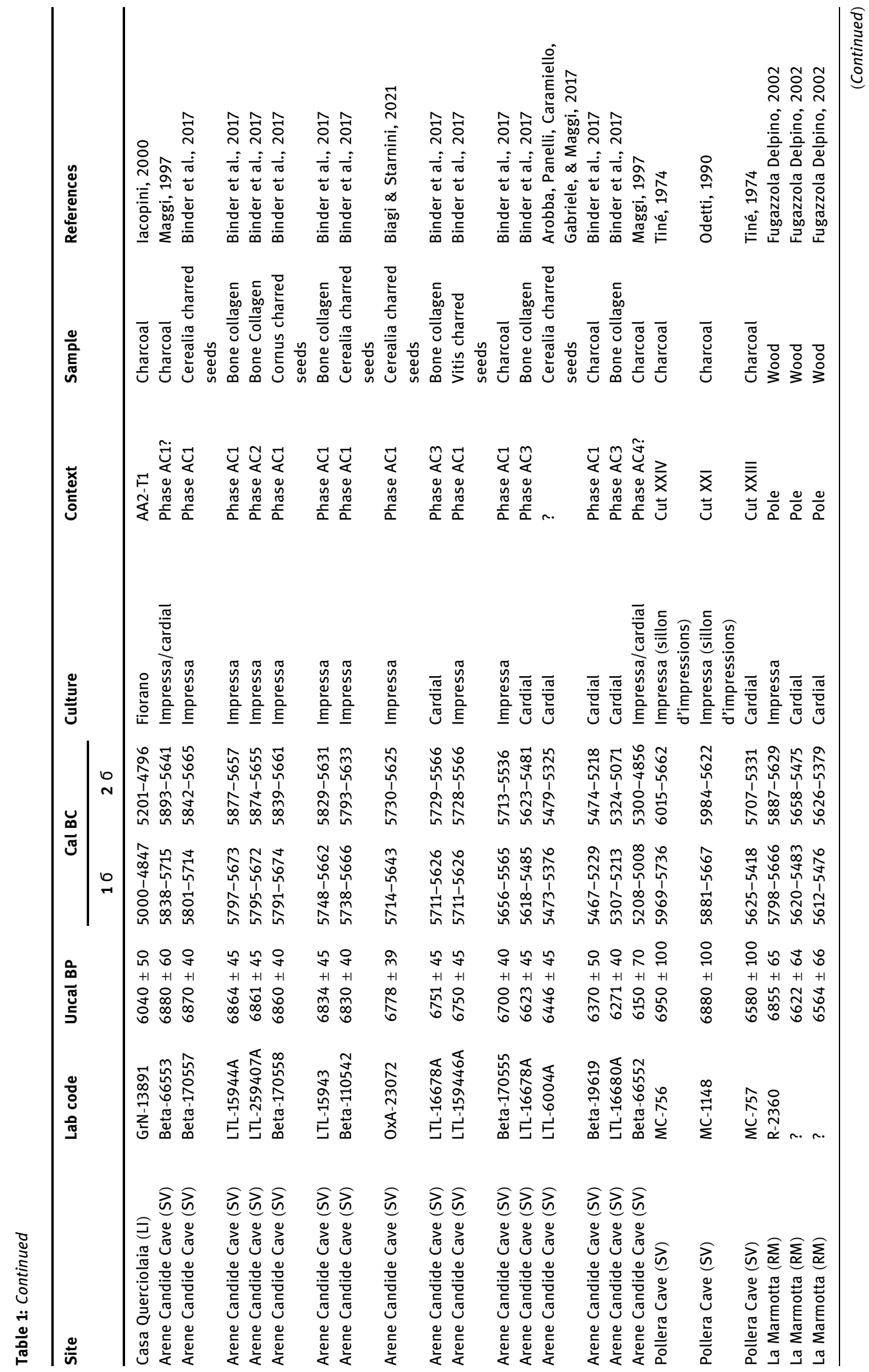




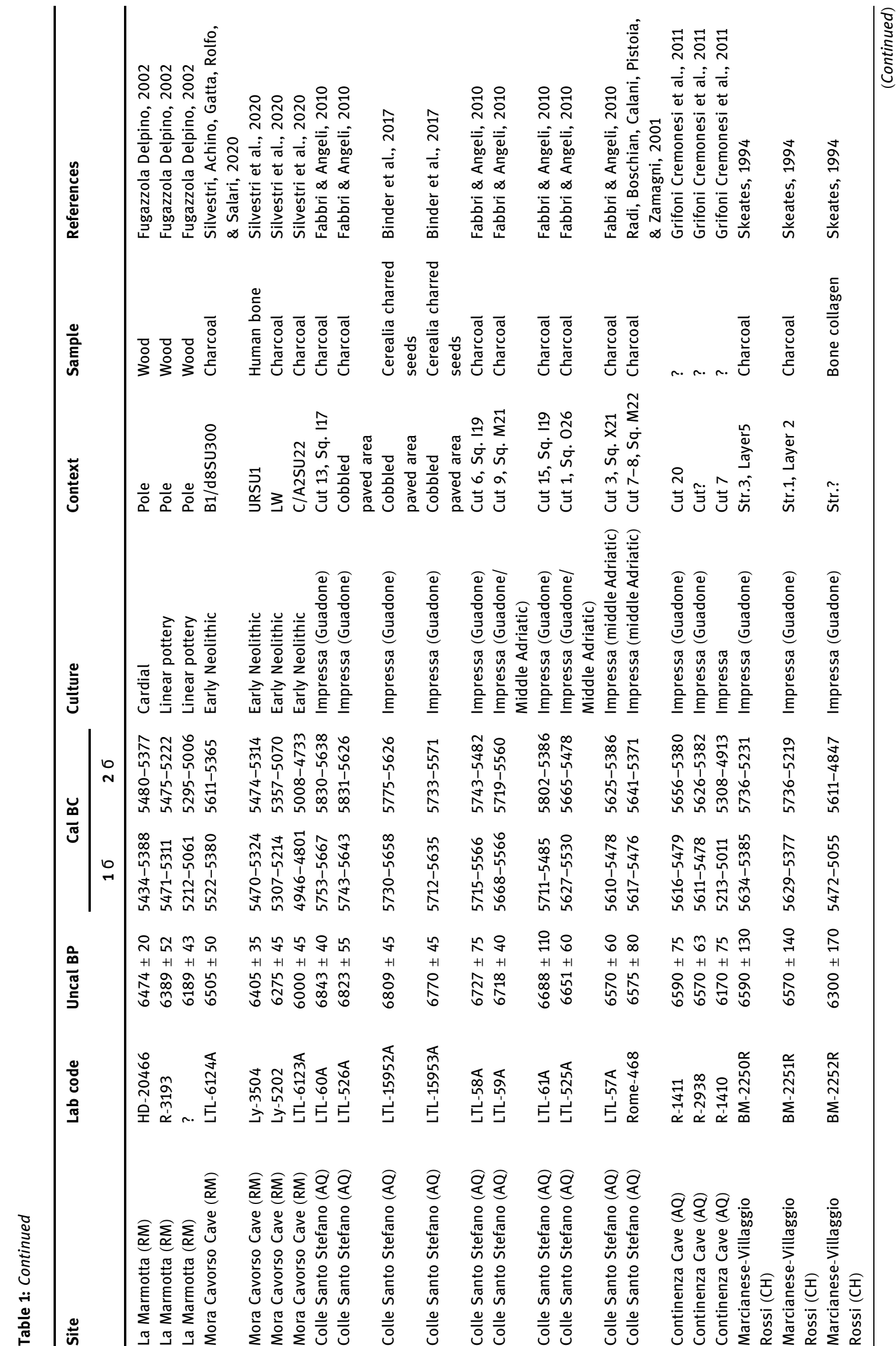




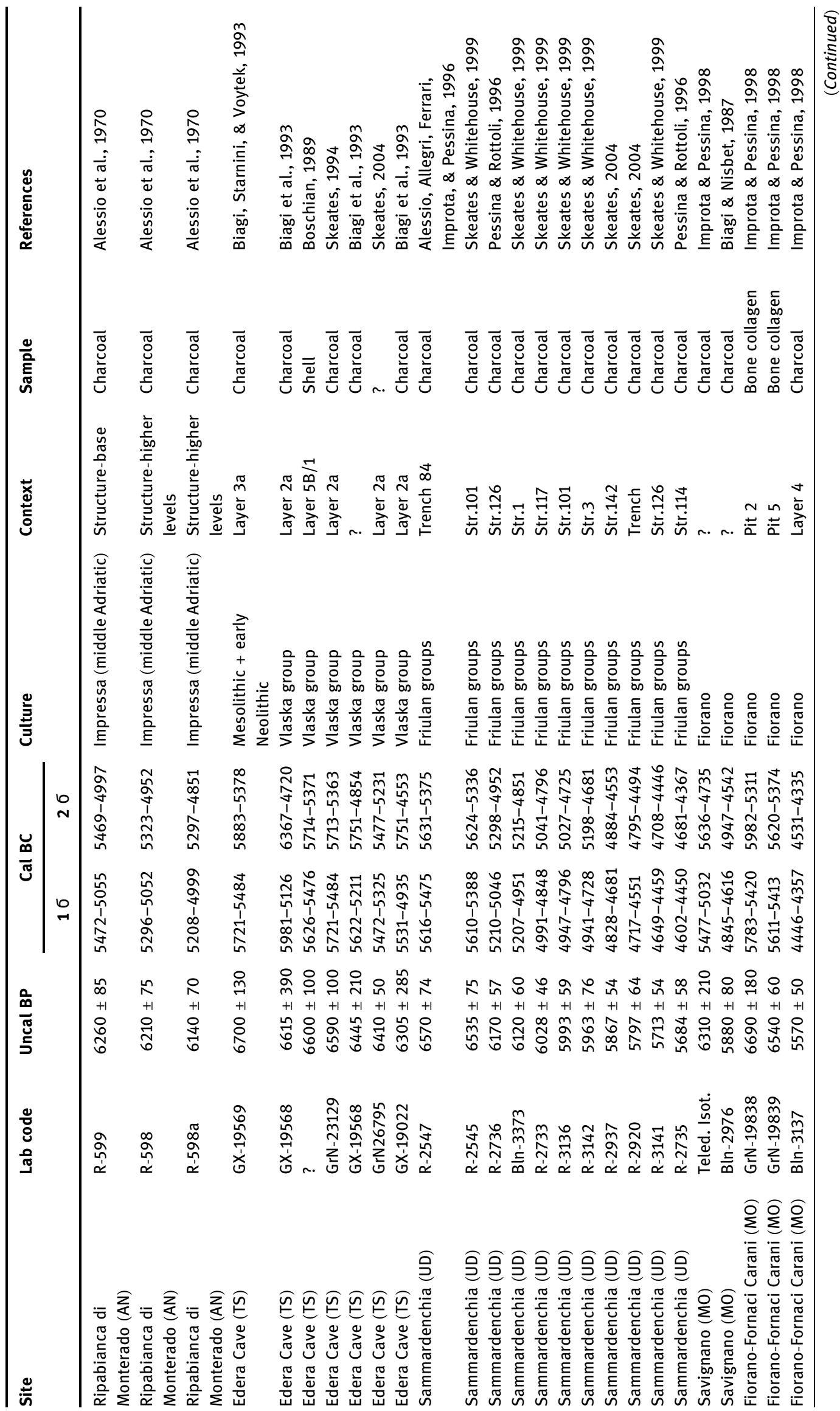




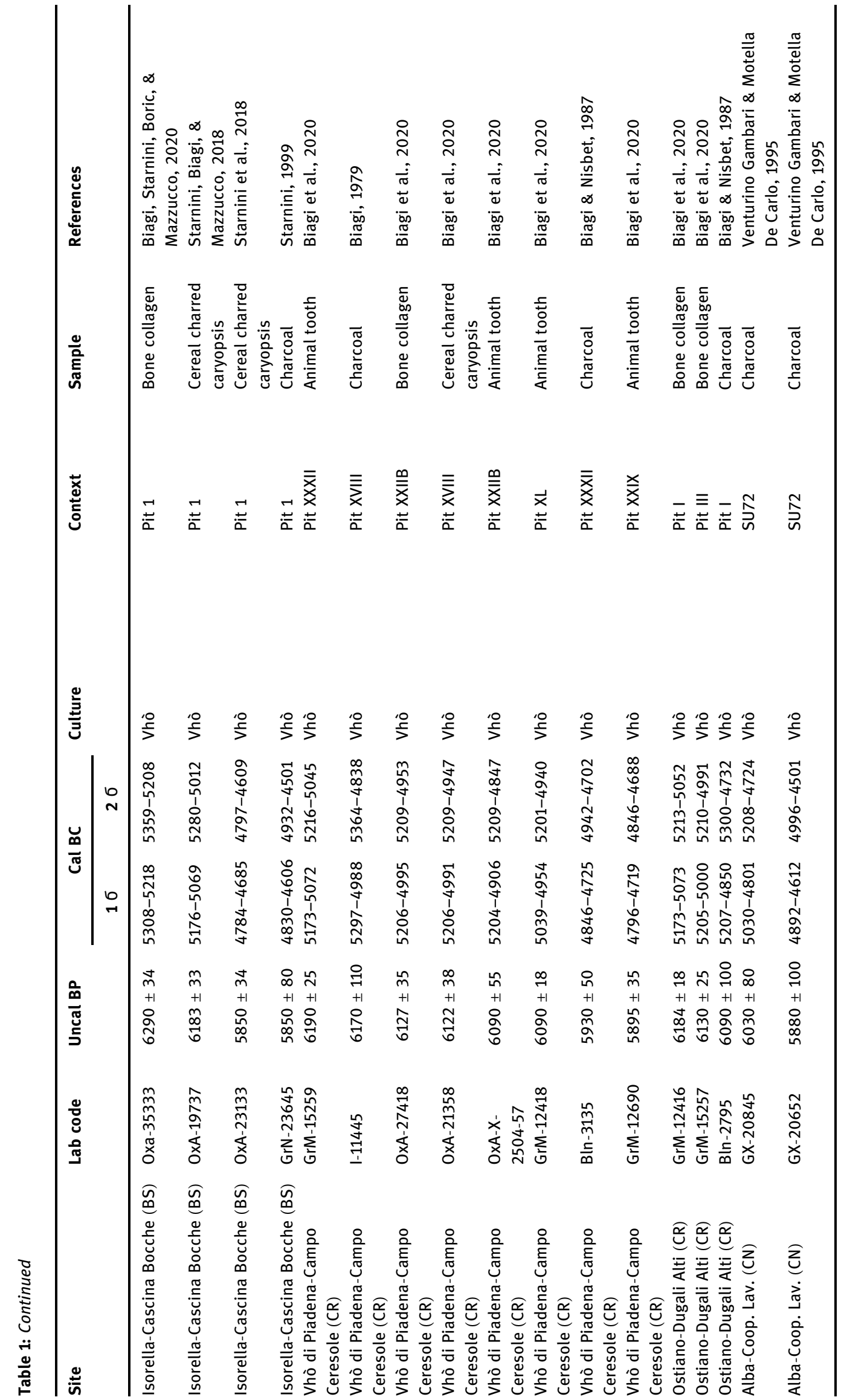


pattern of the vessels, most likely influenced by the different origin of the first settlers and local evolution of their material culture.

The first pioneers on the Tyrrhenian coast, as mentioned earlier, were related to the archaic style of the impressed pottery but were rapidly replaced by the Cardial Ware groups, who spread as far as the FrancoCantabrian area (Binder \& Maggi, 2001; Binder et al., 2017; Guilaine \& Manen, 2007).

The neolithization of the Adriatic coast occurred due to settlers coming from south Italy, linked to an evolved phase of the Impressed Ware Culture. At the beginning of sixth millennium cal BC, they reached the Abruzzi region and then spread to the northernmost area around the middle of the same millennium (Bagolini \& Von Eles, 1978; Pessina, 2002; Radi, 2010, Table 1; Radmilli, 1974).

In northern Italy, apart from the western zones where the impressed ware mentioned earlier is documented, several early Neolithic groups have been recognized, different in geographical distribution and in some aspects of materials culture: Fiorano, Vhò, Isolino, Gaban, Friulani Groups, and Vlaška Group (Bagolini, 1980b; Pessina, 1998; Pessina \& Tiné, 2008). To date, based on available new data, research strictly underlines affinities between some of these groups, the boundaries of which appear increasingly blur (Biagi et al., 2020; Perini, Starnini, D’Amico, \& Ottomano, 2001; Perrin, 2006). Despite the evidence of regionalism, the whole peninsula was crossed by a wide exchange network permitting the circulations of artifacts, raw materials, as well as ideas.

This richness and variety of the cultural framework of the early Italian Neolithic are reflected in the personal adornment habits of the diverse human groups.

\section{Pre-Neolithic Ornamental Tradition}

At the end of the Pleistocene as well as during the early Holocene (Figure 1), despite significant cultural differences between these two periods, the largest part of ornament assemblages was composed of perforated shells, consisting mainly of marine gastropods and bivalves. These shells, often found in sites several kilometers distant from the coastline (Fumane Cave: Aurignacian levels OS-5872 $37100 \pm 240$ BP, UtC-2045 $32300 \pm$ 400, Broglio, 1995; Gurioli, Cilli, Giacobini, \& Broglio, 2005; Peresani et al., 2019; Figure 2a; Riparo Gaban: Castelnovian levels KIA-10365 $8323 \pm 63$ BP, KIA-10363 $6968 \pm 41$ BP, Bagolini, 1980a; Kozlowski \& Dalmeri, 2002; Figure 2b; Riparo Tagliente: Epigravettian level LTL-4441A $13986 \pm 60$ BP, Broglio, 1984; Fontana et al., 2015; Continenza Cave: late Epigravettian levels from LTL-1250a 11983 \pm 80 BP to Rome-557 $10280 \pm 110$ BP, Astuti, Bisconti, Chiarenza, \& Grifoni Cremonesi, 2006; Grifoni Cremonesi, Serradimigni, \& Usala, 2011; Figure 2d(1-5)), prove the existence of long-distance mobility and exchange networks that promoted the penetration of these items into the Alpine and inland areas. The fact that only specific types of shells were selected is probably related to their peculiar ornamental use or symbolic significance (Baysal, 2013).

From the end of the late Epigravettian, the use of Columbella rustica and Cyclope sp. items increases, in particular C. neritea (i.e. Riparo Tagliente: Benini Accorsi, 1974; Settecannelle Cave: GrN-15977 $10570 \pm 260$ BP, OZC-163 $12700 \pm 170$ BP, Ucelli Gnesutta et al., 2006; Pozzo Cave: AA-78136 $12820 \pm 130$ BP, GX-27906 $12320 \pm 50$ BP, Mussi et al., 2000; Delle Mura Cave: Beta-142778 $11420 \pm 100$ BP, Calattini, 2005). Nevertheless, other species of shells such as Glycimeris, Mitra sp., or even the rarer Nassarius reticolata and Dentalium sp. (Antalis dentalis) were collected with the same purpose.

Late Palaeolithic adornment assemblages revealed not only the presence of exchange networks but also the existence of a symbolic language shared or at least understood by the different human groups (Noble \& Davidson, 1996; Roach-Higgins \& Eicher, 1992; Stiner, Kuhn, \& Güleç, 2013; Vanhaeren \& D’Errico, 2006). With the emergence of the Holocene, this "language" undergoes changes. The environmental changes affected the relationship between humans and nature. The human communities had to adapt their daily life to these changes that also inevitably involved their spiritual and symbolic sphere.

During the Mesolithic, the use of Columbella rustica became more predominant (i.e., Romagnano Loc III: Sauveterrian phase from R-1147 $9830 \pm 90$ BP to R-1139 $8220 \pm 70$ BP, Castelnovian phase from R-1137 $7850 \pm 60$ BP to R-1137B $7800 \pm 80$ BP, Alessio et al., 1984; Broglio, 1997; Riparo Gaban: Dalmeri \& 


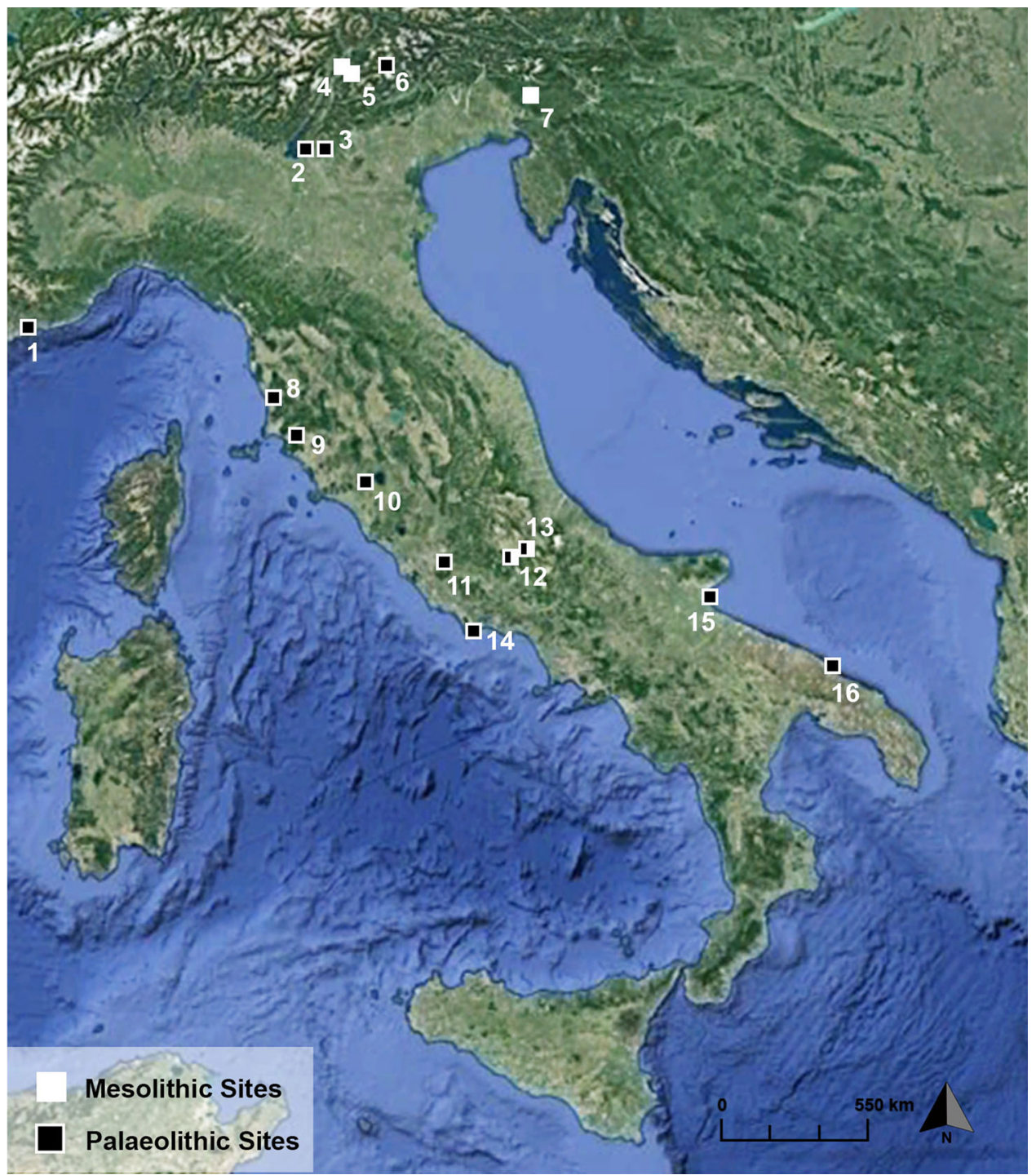

Figure 1: Distribution map of the Italian Mesolithic and Palaeolithic sites mentioned in the text: (1) Riparo Bombrini-Balzi Rossi; (2) Fumane Cave; (3) Riparo Tagliente; (4) Riparo Gaban; (5) Riparo Romagnano; (6) Riparo Villa Bruna; (7) Riparo Biarzo; (8) Monterotondo; (9) Gavorrano; (10) Settecannelle Cave; (11) Polesini Cave; (12) Continenza Cave; (13) Pozzo Cave; (14) Fossellone Cave; (15) Paglicci Cave; and (16) Delle Mura Cave. (Map Data: Google Earth Pro 7.3, Data SIO, NOAA, U.S. Navy, NGA, GEBCO; Image Landsat/Copernicus, elaboration by A.Vassanelli).

Lanzinger, 1997; Figure 2b; Riparo Biarzo: Sauveterrian and Castelnovian levels, Bertolini, Cristiani, Modolo, Visentin, \& Romandini, 2016; Cristiani, 2012), while among the other collected shells, the presence of $C$. neritrea seems to decrease, while the use of Dentalium sp. gains importance.

Other relevant items related to the adornment habit of pre-neolithic groups were modified mammals' bones and teeth. In particular, perforated red deer atrophic canines were widely spread (Riparo Tagliente: late Epigravettian; Riparo Villabruna: late Epigravettian levels from R-2023 $12040 \pm 150$ BP to UtC-1771 11910 \pm 160 BP, Bertola et al., 2007; Polesini Cave: late Epigravettian level R1265 $10090 \pm 80$ BP, Belluomini, 1981; Cremonesi, 1987; Paglicci Cave: Gravettian level UTC-1412 $26800 \pm 300$ BP, Mussi \& Zampetti, 1993; Ronchitelli et al., 2015; Continenza Cave: Epigravettian levels, Sauveterrian levels from Rome-556 $9680 \pm 100$ to Rome-552 $9490 \pm 100$ and Castelnovian level, Grifoni Cremonesi et al., 2011; Figure 2d(6-8)).

Both in the late Palaeolithic and Mesolithic, the occurrence of ornamental artefacts made of stone is rare. The archeological records only document the following categories: 

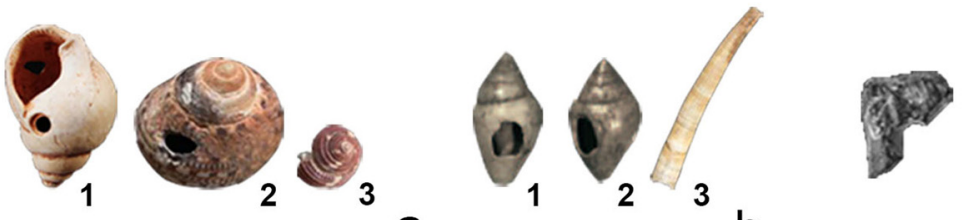

a

b

C
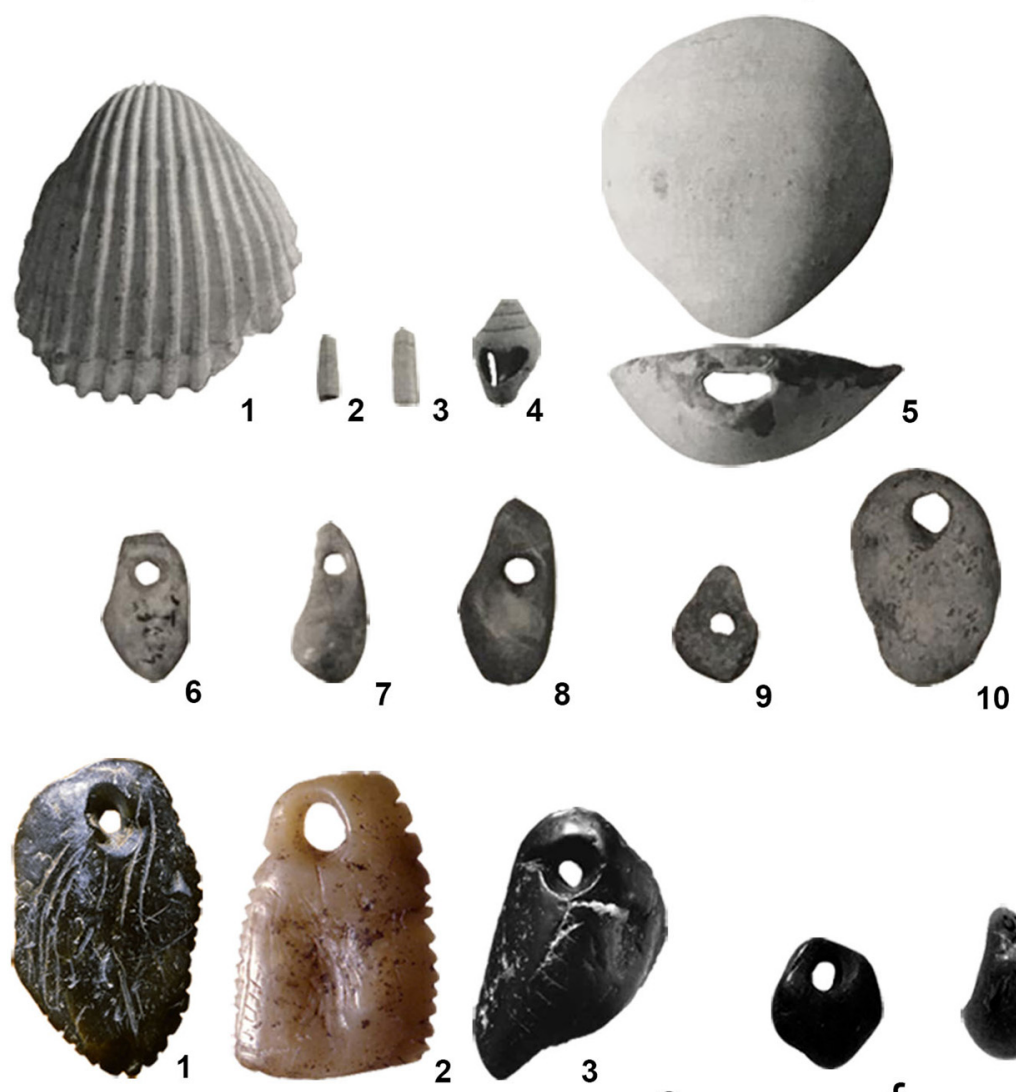

e
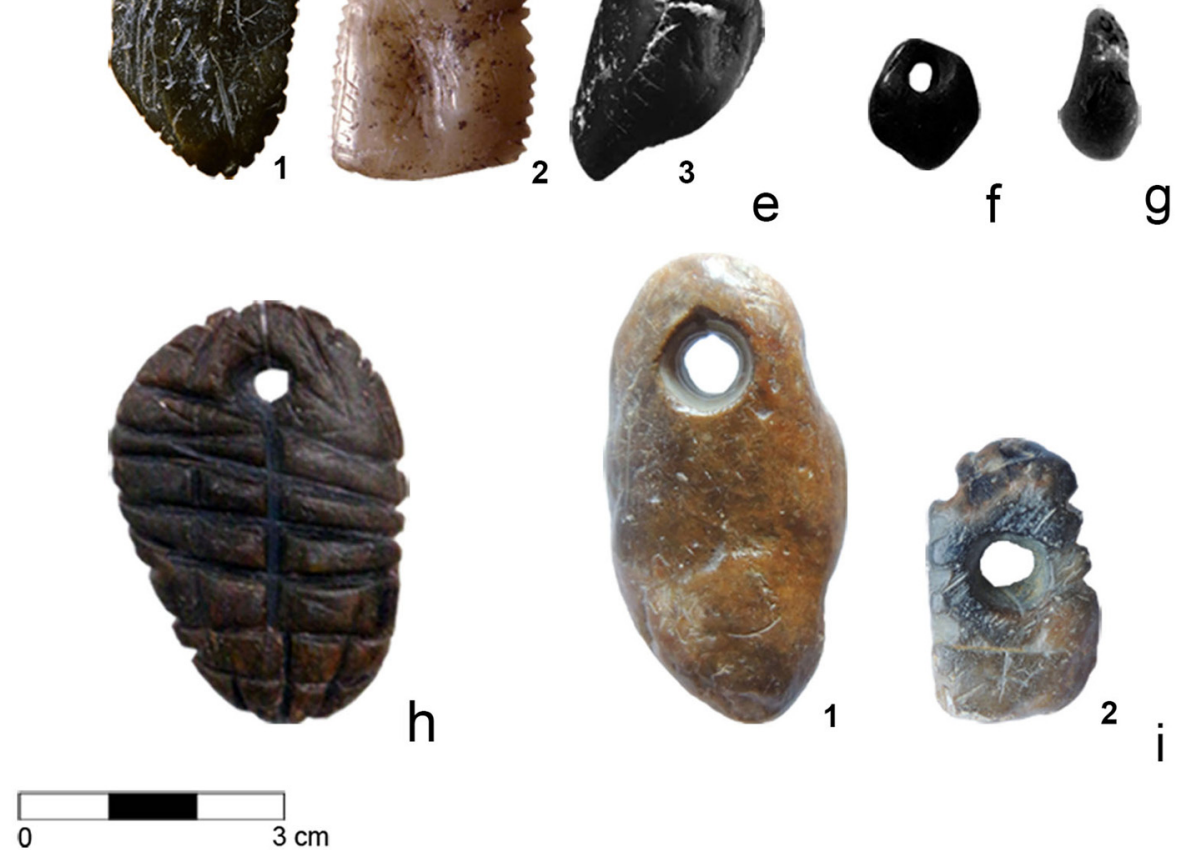

Figure 2: Selection of Italian pre-Neolithic ornaments. (a) Fumane Cave (Peresani et al., 2019); (b) Riparo Gaban (Borrello \& Dalmeri, 2005; Cristiani, 2012); (c) Riparo Bombrini-Balzi Rossi (Bertola et al., 2013); (d) Continenza Cave (Colombo \& Serradimigni, 2016); (e) Settecannelle Cave (photograph by P. Ucelli Gnesutta); (f) Polesini Cave (Mussi, 1991); (g) Fossellone Cave (Mussi, 1991); (h) Gavorrano (photograph by Museo Archeologico di Massa Marittima (Grosseto, Tuscany), CC BY-SA 4.0); and (i) Monterotondo (photograph by A. Vassanelli). Elaboration by A. Vassanelli. 
- Simply perforated items. Small natural pebbles selected to be perforated, with the purpose of being worn or hung on to something (i.e., Monterotondo: late Epigravettian, Vassanelli, 2018; Figure 2i(1); Continenza Cave: late Epigravettian levels; Figure 2d(10); Polesini Cave: late Epigravettian level; Figure 2f).

- Slightly morphologically modified items. They were produced on pebbles, which were selected because their shape was similar to the final desired morphology. The human modification was focused mainly on the surface's treatment, richly decorated with linear carvings (i.e., Monterotondo: late Epigravettian; Figure 2i(2); Settecannelle Cave: late Epigravettian; Figure 2e; Gavorrano: Epigravettian, Lo Vetro, Balducci, \& Volante, 2007; Figure 2h).

- Modified items. Some stones had undergone a more elaborate manufacturing process, where their natural shape was exploited to recreate some specific templates (Riparo Bombrini: proto-Aurignacian level Beta-204028 34.200 \pm 500, Bertola et al., 2013; Figure 2c). These items often intentionally imitate the shape of a deer's atrophic canines (i.e., Continenza Cave: late Epigravettian level; Figure 2d(9); Fossellone Cave: Aurignacian level; Figure 2g).

\section{Neolithic Personal Ornaments}

With the neolithization, several changes related to raw material, shape, manufacture quality, and technology as well as the suspension mode occur in the ornamental repertoire of the Italian peninsula.

The exploitation of hard animal matter, recalling the previous tradition, continues alongside a significant increment in the use of stone materials, connected to an increase in manufacture complexity.

Data indicate the emergence of high-modified items' productions, with differences in geographical distribution and raw material selection (Figure 3).

These new stone ornament productions can be considered as a marker of the demic migrations who settled the peninsula and are therefore a representation of the new cultural aspects developing in the different areas (Pessina \& Tiné, 2008).

The presence in the early Neolithic ornamental assemblage of new types along with pre-Neolithic ones reflects the ornamental trend observed in Southern and Central Europe (Rigaud, D'Errico, \& Vanhaeren, 2015).

Among the stone ornaments, pendants are few and scattered throughout the peninsula. The use of the engraved decoration disappears completely, and their shape became more regular and well defined.

Ring bracelets and shaped beads, mainly the discoid one, appear for the first time in the ornamental repertoire. The former shows a particular geographical concentration, while shaped beads have a wider diffusion. The sources of lithic raw materials used were mainly local and were collected in outcrops or riverbanks. However, steatite, greenstone, and marble artifacts have been found in sites far from the outcrops, revealing the existence of a long-distance exchange system and the choice of hard materials for specific items. Shell and bone were also employed, in some cases preferred, to obtain these new shaped ornaments.

\subsection{Stone Pendants}

There is a scarce occurrence of lithic pendants dated to the beginning of the early Neolithic, mostly consisting of minimally processed items, obtained by local raw materials.

One of the earliest was found at Torre Sabea (OxA-3950 $6860 \pm 45$ BP; Cremonesi et al., 1987; Guilaine \& Cremonesi, 2003; Table 1). This pendant, in amber calcite, has a rough morphology and is broken at one end, where the trace of a little biconical perforation (Radi, 2003; Figure 4b) is clearly visible. 


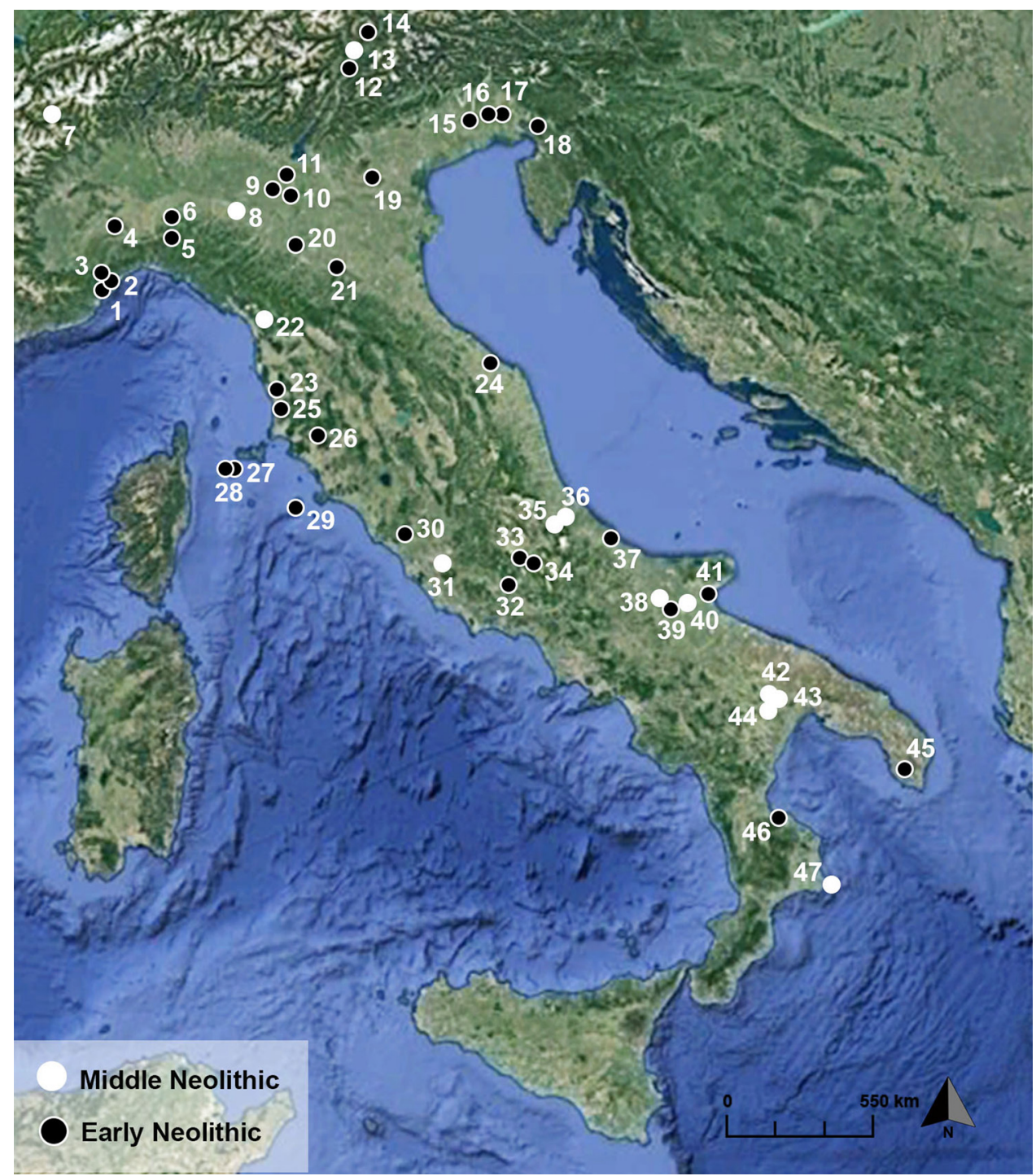

Figure 3: Distribution map of the Italian early and middle Neolithic sites mentioned in the text: (1) Arene Candide Cave; (2) Pollera Cave; (3) Arma delle Anime Cave; (4) Alba; (5) Brignano Frascata; (6) Monte Alfeo-Godiasco; (7) Vollein; (8) Sant'Andrea di Travo; (9) Ostiano-Dugali Alti; (10) Vhò di Piadena (Campo Ceresole and San Lorenzo); (11) Isorella-Cascina Bocche; (12) Riparo Gaban; (13) La Vela; (14) Riparo Plunacker; (15) Cesena di Azzano; (16) Buttrio; (17) Sammardenchia; (18) Edera Cave; (19) Ca' Bissara; (20) Fiorano-Fornaci Carani; (21) Savignano; (22) All’Onda Cave; (23) Casa Querciolaia; (24) Ripabianca di Monterado; (25) Castagneto Carducci; (26) Fontino Cave; (27) Cala Giovanna Piano-Pianosa Island; (28) La Scola-Pianosa Island; (29) Le Secche-Giglio Island; (30) La Marmotta; (31) Casali di Porta Medaglia; (32) Mora Cavorso Cave; (33) Continenza Cave; (34) Colle Santo Stefano; (35) Catignano; (36) Villa Badessa; (37) Villaggio Rossi di Marcianese; (38) Mulino da Basso; (39) Ripatetta; (40) Passo di Corvo; (41) Coppa Nevigata; (42) Tirlecchia; (43) Murgia Timone; (44) Malvezzi; (45) Torre Sabea; (46) Favella della Corte; and (47) Capo Alfiere. (Map Data: Google Earth Pro 7.3, Data SIO, NOAA, U.S. Navy, NGA, GEBCO; Image Landsat/Copernicus, elaboration by A. Vassanelli).

Related to the same period are two sub-rectangular pendants, fractured at the level of the hole, coming from the Arene Candide Cave (Traversone, 1999; Figure 4a). Moving on to the north-eastern side of the peninsula, some greenstone pendants have been found at the site of Sammardenchia (D’Amico, 1998; Figure 4c).

The only piece that indicates a more elaborate manufacturing process is the pendant of Colle Santo Stefano in Abruzzi (Petrinelli Pannocchia \& Vassanelli, 2016; Figure 4d; Table 1). This elongated item, made in actinolite, has a plano-convex cross-section with extremely polished surfaces. To date, it is impossible to 


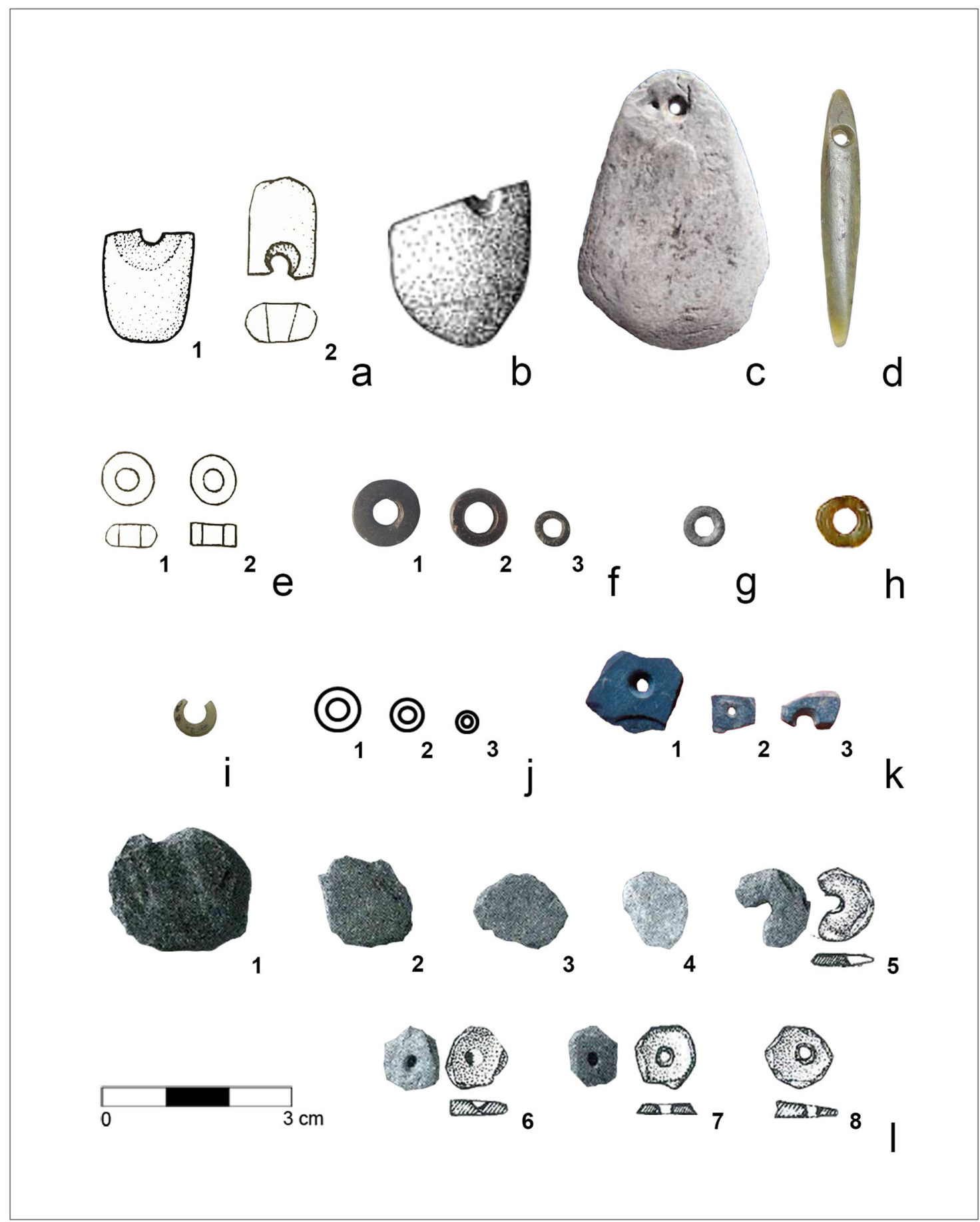

Figure 4: Selection of Italian early Neolithic stone pendants and shaped beads. (a) Arene Candide Cave (Traversone, 1999); (b) Torre Sabea (Radi, 2003); (c) Sammardenchia (D’Amico, 1998); (d) Colle Santo Stefano (Petrinelli Pannocchia \& Vassanelli, 2016); (e) Arene Candide Cave (Traversone, 1999); (f) Cala Giovanna Piano-Pianosa Island (Bisconti \& Zamagni, 2007); (g) Mora Cavorso Cave (Silvestri et al., 2020); (h) Ripabianca di Monterado (Lollini, 1991); (i) Pollera Cave (photograph by A. Vassanelli); (j) La Marmotta (Micheli, 2003); (k) Favella della Corte (Micheli, 2009); and (l) Le Secche-Giglio Island (Brandaglia, 1987). Elaboration by A. Vassanelli.

determine the specific supply area of the raw material. However, suitable sources have been identified in Calabria and in the northern Apennine (Mottana, Crespi, \& Liborio, 2004). It is impossible to ascertain if the raw material or the finished object was imported. 
At Piccioni Cave (Cremonesi, 1976), in a level dated to the end of the early Neolithic, an ovoid stone pendant was recovered, which had an engraved line encircling the middle of its surface.

From the end of the early and the beginning of the middle Neolithic, the shape of the pendants became more defined, tending toward a geometrical morphology, often trapezoidal or sub-rectangular, but not properly standardized. In the literature, the trapezoidal and thin elongated shaped ones are often defined as miniature axe-heads or chisels, probably with a ritual value (i.e., Passo di Corvo: Tiné, 1983; Capo Alfiere: Morter \& Robb, 2010; Murgia Timone, Tirlecchia: Aurino \& Mancusi, 2016).

It is interesting to observe that some geometric pendants found in Apulia were exclusively made of jadeite, very similar in color and translucency with the raw material used for the early Neolithic pendant of Colle Santo Stefano. Conversely, in central-northern Italy, the middle Neolithic stone ornaments show a preferential use of dark-colored soapstone. During the last phase of the Neolithic, pendants become more common (i.e., Mulino da Basso: Gravina, 2014; Casali di Porta Medaglia: Carboni \& Anzidei, 2020; All’ Onda Cave: Amadei \& Grifoni Cremonesi, 1986-1987; Sant'Andrea di Travo, Vollein: Micheli, 2016), both in burials and settlements, mostly in north Italy.

\subsection{Stone-Shaped Beads}

With the advent of the Neolithic, the use of shaped beads spread throughout the Italian peninsula. Morphologically and technically different from the ornaments of the Palaeolithic and Mesolithic, these beads probably represent a new way in which the people adorned themselves.

The discoid type represents the most abundant category, and their simple shapes may recall the late Paleolithic and Mesolithic tradition of using fish vertebrae as necklace elements (i.e., Balzi Rossi: Gravettian burials BG2,3,5, Formicola, 1988; Polesini Cave, Epigravettian levels; Riparo Gaban, Castelnovian levels). The next most important is the cylindrical shape, usually the short type, while other forms are rarer: i.e., bottle, ovoid, and ring shape. Since, in general, they are recovered in smaller numbers, it can be suggested that they were worn as part of heterogenic compositions, as some finds in the Near East indicate (Baysal, 2019).

The distribution of this type of ornament highlights clearly the time and trajectories of the Neolithic penetration into central-south Italy. Unfortunately, the archeological evidence and the absolute dates at our disposal are extremely limited.

At Favella della Corte (Tiné, 2009), dated to the first centuries of sixth millennium cal BC, Micheli (2009) pointed out the presence of a beads workshop, which used radiolarite, ophiolite, and serpentine indifferently. The five unfinished beads recovered (Figure 4k) testify to a manufacture sequence starting from flakes, which were shaped by rough grinding, then perforated, and finally calibrated and polished. It is also important to underline the production of terracotta beads carried out on this site.

Another attestation in the south is the limestone bottle-shaped bead, found at Coppa Nevigata (Puglisi, 1955).

Along the Tyrrhenian coast, four preform beads, four shale beads, and one quartz bead have been discovered at Serotino-Le Secche (Giglio Island: Brandaglia, 1987; Figure 4l). These beads were shaped through a flaking retouch of the edges and only in a few cases show traces of grinding.

For this site, there are no radiocarbon dates, but the associated pottery allowed us to attribute Le Secche to the beginning of the early Neolithic.

Moving further north, three discoidal siltstone beads and a nonperforated steatite cylinder have been discovered in the Impressed Ware levels of the Arene Candide Cave, in Liguria (Traversone, 1999; Starnini \& Voytek, 1997; Figure 4e and i).

The presence of preforms at Favella della Corte, Arene Candide Cave, and Le Secche points to a local production of beads, employing raw materials available in the immediate surroundings of the sites.

Along the same coastline, stone-shaped beads have been found in slightly later early Neolithic contexts. 
At La Marmotta (Fugazzola Delpino, D’Eugenio, \& Pessina, 1999; Table 1), numerous discoid and short cylindrical beads occur with different dimensions (Figure 4j). Despite the absence of a comprehensive study, it is possible to observe a certain standardization of these beads, showing calibrated perforations to the diameter and well-defined surfaces.

In the same region, one of the rare attestations of beads found within a burial context occurs, which dates to the second half of the sixth millennium cal BC. In the inner room sector of Mora Cavorso Cave (Silvestri et al., 2020; Table 1), about 28 burials associated with a few grave goods, composed of pottery, flint artifacts, as well as beads in shell and stone, have been found (Figure 4g).

Slightly more recent are the eight serpentinite and four steatite discoid beads found at Cala Giovanna Piano (Tuscan archipelago) (Bisconti \& Zamagni, 2007; Figure 4f). Four of them, due to the width of the hole, can be better classified more specifically as ring beads. The raw materials used, not available on the island, as well as the absence of bead blanks, suggest their importation.

During several surveys in the Livorno's territory of Tuscany (Vassanelli, 2018), 119 pieces, including blanks and finished stone beads, were collected. Despite the absence of chronological information, the morphology and the manufacturing process suggest a Neolithic attribution of some of these items.

The evidence in the Northern area and along the Adriatic coast are even poorer.

At Monte Alfeo-Godiasco (Simone Zopfi, 2004), a site attributed to the Vhò culture one blank bead has been found, associated with one ring and one discoid steatite bead. Based on literature reports, similar findings are also testified at the sites of Riparo Gaban (Borrello \& Dalmeri, 2005) and Sammardenchia (Micheli, 2009; Table 1). In the former, some short limestone cylindrical beads have been identified, and in the second, a few paragonite schist beads.

Belonging to the early Neolithic of the Istria region are four very small, perforated beads made of sandstone, discovered at the Edera Cave (Biagi, Starnini, \& Voytek, 2008). These beads were found in a stratigraphic unit (3a) containing few potsherds and domesticated animal bones, dated to the first centuries of sixth millennium cal BC (Biagi, 2003).

At the Pollera Cave, one green steatite discoidal bead, referable to the end of the early Neolithic/ beginning of the middle Neolithic, has been recovered (Odetti, 1990; Figure 4i).

The evidence of stone beads production in northern Italy increases from the fifth millennium cal BC with the spread of the Square Mouth Pottery culture (Mazzieri \& Micheli, 2007, 2014). The use of the black steatite beads became almost exclusive.

On the Adriatic coast, a discoid steatite bead at Ripabianca di Monterado (Lollini, 1991; Figure 4h) and two beads, one globular and one long cylindrical, in the Villaggio Rossi of Marcianese (Geniola, 1982) have been discovered.

\subsection{Stone Ring Bracelets}

Contemporary to the neolithization of northern Italy, the use of ring stone bracelets spread (Pessina, 1998; Ribero, 2017; Tanda, 1977).

According to Micheli (2012), the distribution of these ornamental objects was "trans-cultural and had a long-lasting tradition as an important component of Neolithic costume.” From the middle of sixth millennium cal BC, occurrences of these objects are numerous ranging from the Alpine region to the Emilia (i.e., Località Plunacker: Dal Ri, 1996; Isorella-Cascina Bocche: Starnini, 1998; Figure 5d; Vhò di Piadena-San Lorenzo, Vhò di Piadena-Campo Ceresole: Baioni \& Starnini, 2008; Figure 5e; Sammardenchia, Cesena di Azzano Decimo, Buttrio: Pessina, 1993; Figure 5a; Savignano, Fiorano-Fornaci Carani: Laviosa Zambotti, 1943; Figure 5c). In Tuscany, of a slightly later date, evidence has been found at Castagneto Carducci (Sammartino, 2007) and Casa Querciolaia (Iacopini, 2000) in layers referred to the Fiorano Culture.

At Alba-Cooperativa Lavoratori (D’Amico \& Ghedini, 1996) and Brignano Frascata (Zamagni, 1996; Figure 5b), numerous blanks at different stages of production were found, permitting the reconstruction of the whole manufacturing chain (D'Amico, 1998). In general, metamorphic rocks of the greenstone group 


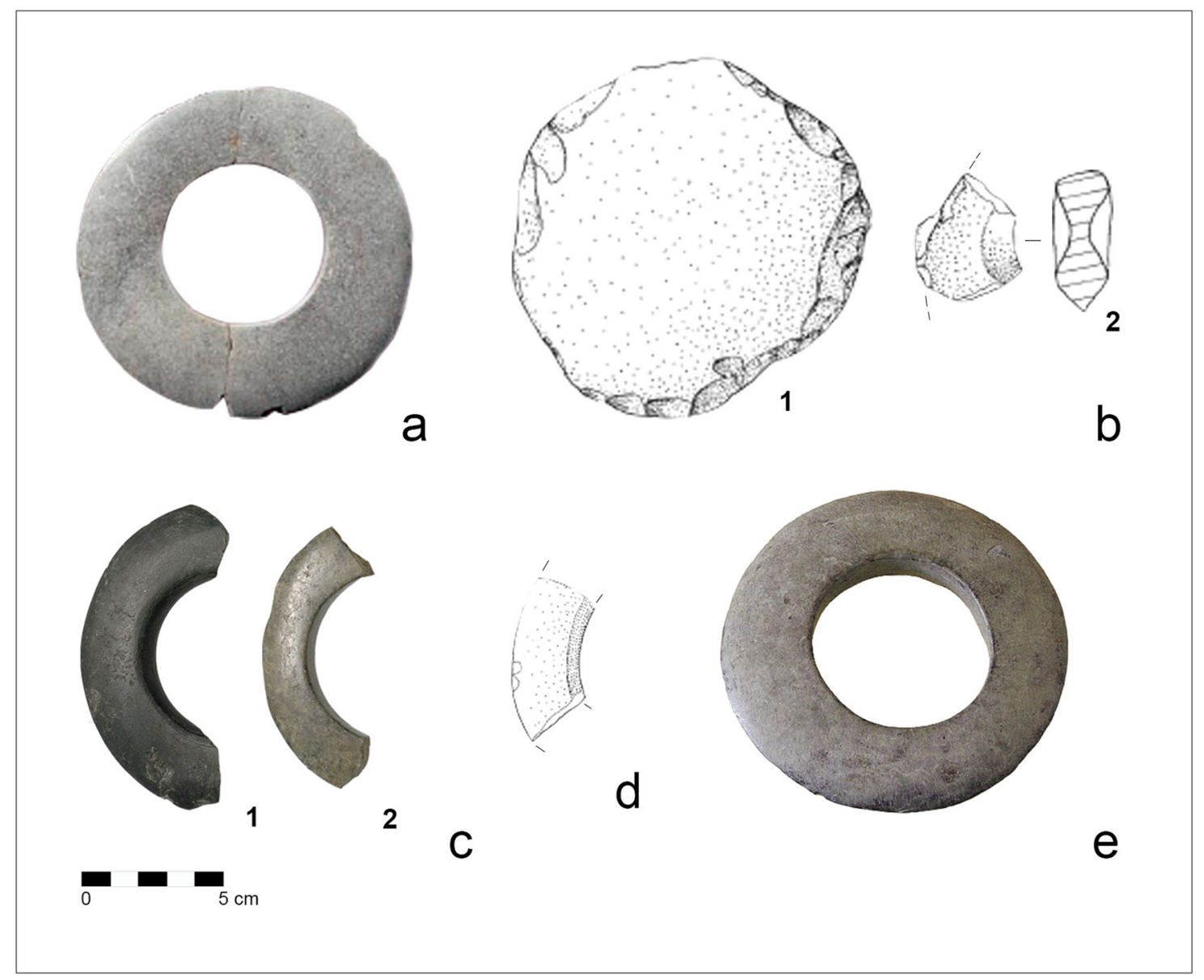

Figure 5: Selection of Italian early Neolithic stone ring bracelets. (a) Sammardenchia (Pessina, 1998); (b) Brignano Frascata (D’Amico, Starnini, \& Voytek, 2000); (c) Fiorano-Fornaci Carani (photograph by Museo Civico di Modena (Emilia-Romagna)); (d) Isorella-Cascina Bocche (Starnini, 1998); and (e) Vhò di Piadena-San Lorenzo (Baioni \& Starnini, 2008).

were those most largely employed in the manufacture of arm rings. However, differences have been recognized in the exploitation of raw materials within the different northern cultural groups, probably relating to the availability of the supplying area as well as the preference for peculiar raw materials.

During the middle and final Neolithic, this kind of ornament also spread to the remainder of the Peninsula, as shown by the numerous examples at Pollera and Arene Candide.

In the Adriatic area, two steatite bracelet fragments, probably arrived from the Tyrrhenian coast, have been found at Catignano (Zamagni, 2003) and Villa Badessa di Cepagatti (Radi, 1980). In the former, a fragment made in quartz was also collected. In the south, evidence of these objects is extremely rare (Picciano-Malvezzi in Basilicata: Cremonesi, 1976), suggesting occasional imports from external cultural spheres.

Evidence of repair on the broken items has been found, testifying the importance and the symbolic value of this type of ornaments.

\subsection{Ornaments Made from Hard Animal Materials}

Most of the data available relating to the Neolithic ornament repertories show the persistence of a widespread use of pierced animal tusks and teeth, fish-vertebrae, and processed bones (Figure 6). 


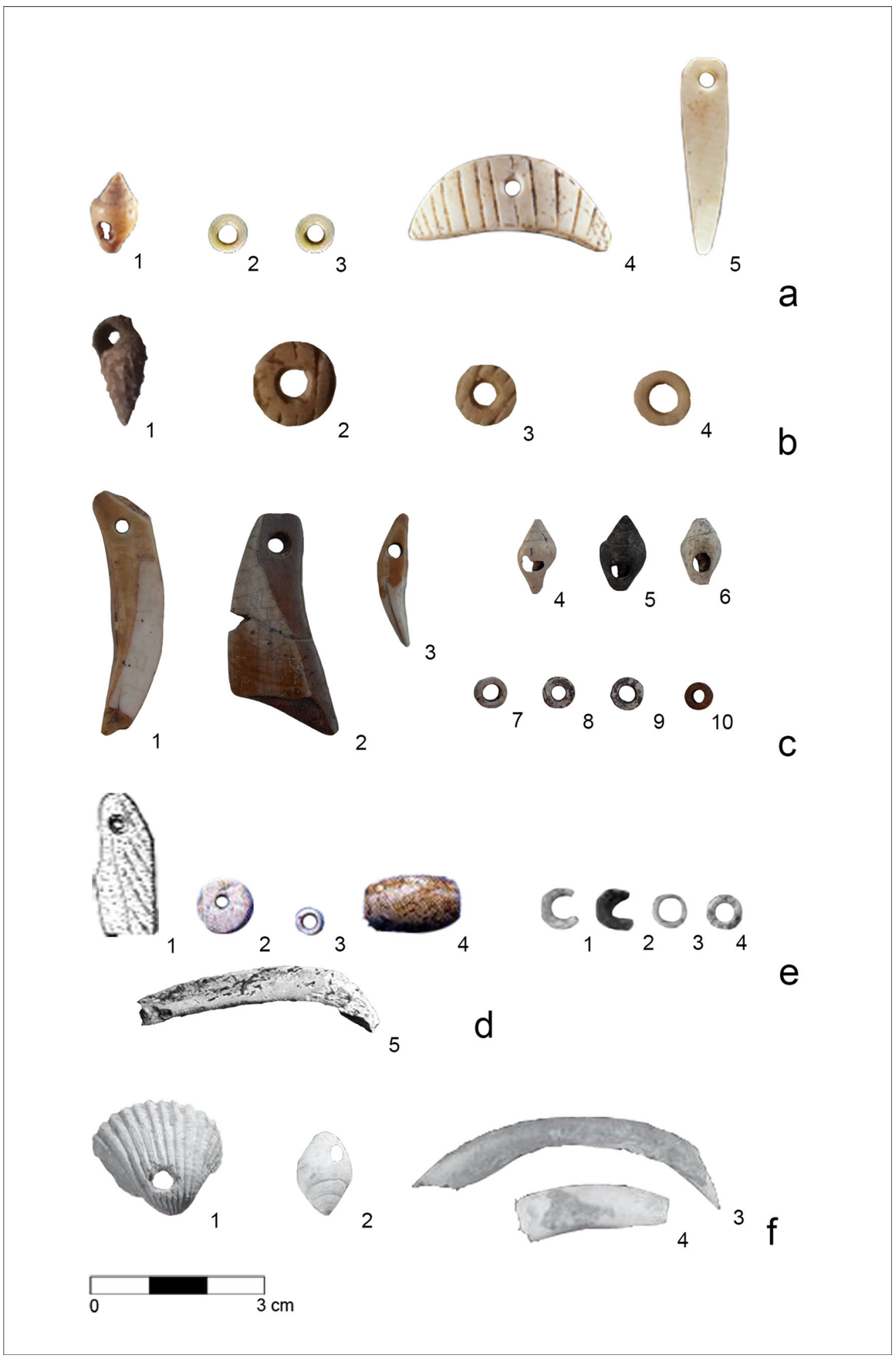

Figure 6: Selection of Italian early Neolithic hard animal matter ornaments. (a) Arene Candide Cave (Borrello, 2005; Micheli, Panelli, Rossi, \& Maggi, 2018); (b) Cala Giovanna Piano-Pianosa Island (Bisconti \& Zamagni, 2007); (c) Colle Santo Stefano (Graniti, 2008); (d) Torre Sabea (Micheli, 2003; Radi, 2003); (e) Mora Cavorso Cave (Silvestri et al., 2020); and (f) Ripatetta (Zamagni, 2006). Elaboration by A. Vassanelli. 
In northern Italy, the presence of Columbella rustica, Cyclope neritea, Cardium (Cerasoderma), and Dentalium associated with limestone-shaped beads in the early Neolithic levels of Riparo Gaban (Borrello \& Dalmeri, 2005) underline a clear continuity with the Castelnovian period. The same situation is shown by numerous sites of the central and south of the peninsula (i.e., Arene Candide Cave: Figure 6a(1); La Scola: Ducci, Guerrini, \& Perazzi, 2000; Cala Giovanna Piano: Figure 6b(1); Mora Cavorso Cave; Ripatetta: Figure 6f(1 and 2); Torre Sabea: Radi, 2003).

At Colle Santo Stefano the majority of the 67 ornaments collected (Graniti, 2008) is represented by Dentalium, fragments of Cardium, and Columbella rustica (Figure 6c(4-6)). Some pendants were obtained from bone: three are on long bones and one Ovis aries phalanx. In addition, some Sus scrofa tusks and four perforated carnivores' teeth (Felis silvestris and Martes) were found (Figure 6c(1-3)).

Since the beginning of the Neolithic, the manufacturing of ornaments also involved the use of shells and bone to produce the shaped beads (i.e., Ostiano-Dugali Alti: Biagi, 1995; Pollera Cave).

At the Arene Candide Cave, among the early Neolithic ornament assemblage mentioned earlier, three discoid shell beads must be added (Figure $6 \mathrm{a}(2$ and 3$)$ ). This production persists into subsequent Neolithic phases at the same site and in other northern contexts, such as the Spondylus cylindrical beads in the grave goods of la Vela di Trento prove (Bagolini, 1990; Micheli, 2012).

Along the Tyrrhenian coast examples of shaped organic beads have been found at Cala Giovanna Piano (Figure 6b(2-4)) and in the Mora Cavorso Cave (Figure 6e). Along the Adriatic coast, at Colle Santo Stefano (Figure $6 \mathrm{c}(7-10)$ ) and at Torre Sabea, the only shaped beads recovered were made with hard animal matter (Figure 6d(2-4)). The shell was exploited the most (Colle Santo Stefano: 4; Torre Sabea: 3), and only one piece from Colle Santo Stefano was made from the bone.

Ring bracelets were also made from the bone (i.e., Isorella-Cascina Bocche) and, more commonly, in the shell. Spondylus and Glycymeris were the most suitable shells, but rare examples are also in Charonia sp. (Arene Candide Cave). The earliest evidence of shell ring bracelets come from southern Italy, at Ripatetta (Figure $6 \mathrm{f}(3$ and 4$)$ ) and Torre Sabea (Figure $6 \mathrm{~d}(5))$. Most of the evidence, however, comes from northern Italy (i.e., Ca' Bissara, Isorella-Cascina Bocche: Micheli, 2005; Fiorano Modenese: Starnini, Ghisotti, Girod, \& Nisbet, 2000), where these kinds of ornaments often accompany the stone ones.

At Arene Candide Cave, in a layer dated to the end of early Neolithic and mostly in the upper Square Mouth Pottery layers, numerous fragments of Spondylus were found, which probably can be interpreted as evidence of a ring bracelets workshop. Belonging to this same cultural horizon are other examples that have been found in Liguria, at Pollera Cave (Bernabò Brea, 1946) and Arma delle Anime Cave (Giuggiola, Imperiale, Lamberti, Piacentino, \& Vicino, 1966).

\section{Discussion and Final Remarks}

During our overview, peculiar aspects emerged that deserve some evaluation and consideration.

Data at our disposal show that the stabilization and the social definition of the early Neolithic communities have been a slow and complex process that the study of the ornaments can help to identify. Throughout the whole peninsula, most production of personal ornaments was made using shells and hard animal matter. Therefore, the spread of new ornamental practices does not seem to have marked the end of the previous traditions.

From the beginning of the Neolithic, visible differences in both the types of ornament distribution and the use of specific raw materials testifies to the variety of the cultural traditions prevalent among the farmers spreading along the peninsula (Figure 7).

The earliest shaped stone beads are in the south and along the Tyrrhenian coast, clearly underlining the trajectory of the spread of the pioneers who first reached the southern regions of the peninsula and then quickly moved northward along the Tyrrhenian coast (Favella della Corte, Serotino-Giglio Island, Arene Candide Cave, Binder \& Maggi, 2001; Binder et al., 2017; Guilaine \& Manen, 2007; Guilaine, 2018; Figure 7a; Radi \& Petrinelli Pannocchia, 2018). It is interesting to note, and maybe not by accident, that the pottery 

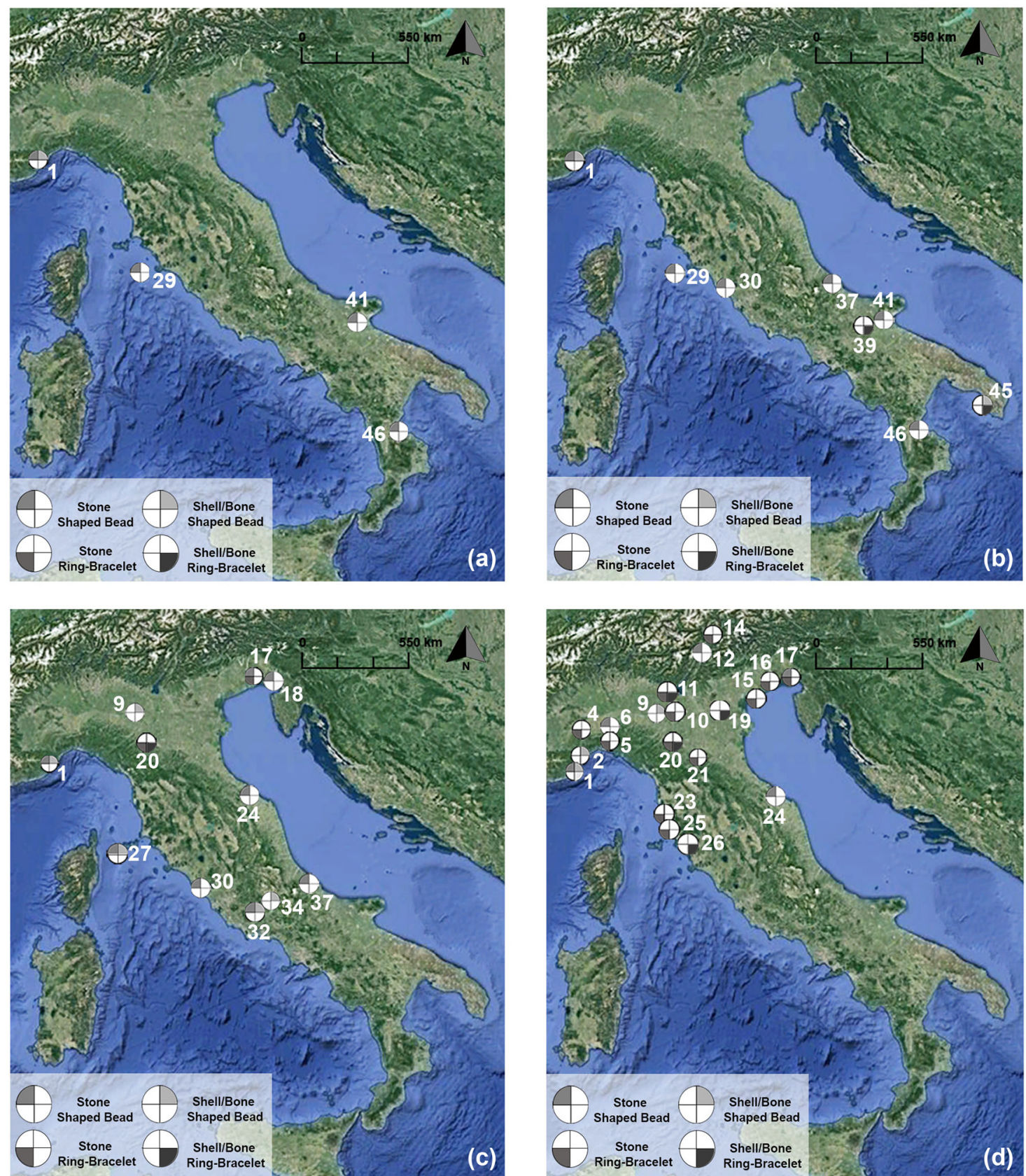

Figure 7: Spread of shaped beads and bracelets across the Italian peninsula during the early Neolithic, based on radiocarbon dates and excavation data: (a) 6000-5800 cal BC: (1) Arene Candide Cave; (29) Le Secche-Giglio Island; (41) Coppa Nevigata; and (46) Favella della Corte. (b) 5800-5600 cal BC: 1, Arene Candide Cave; (29) Le Secche-Giglio Island; (30) La Marmotta; (37) Villaggio Rossi di Marcianese; (39) Ripatetta; (41) Coppa Nevigata; (45) Torre Sabea; and (46) Favella della Corte. (c) 5600-5300 cal BC: (1) Arene Candide Cave; (9) Ostiano-Dugali Alti; (17) Sammardenchia; (18) Edera Cave; (20) Fiorano-Fornaci Carani; (24) Ripabianca di Monterado; (27) Cala Giovanna Piano-Pianosa Island; (30) La Marmotta; (32) Mora Cavorso Cave; (34) Colle Santo Stefano; and (37) Villaggio Rossi di Marcianese. (d) After 5300 cal BC: (1) Arene Candide Cave; (2) Pollera Cave; (4) Alba-Coop. Lav.; (5) Brignano Frascata; (6) Monte Alfeo-Godiasco; (9) Ostiano-Dugali Alti; (10) Vhò di Piadena (Campo Ceresole and San Lorenzo); (11) Isorella-Cascina Bocche; (12) Riparo Gaban; (14) Riparo Plunacker; (15) Cesena di Azzano; (16) Buttrio; (17) Sammardenchia; (19) Ca' Bissara; (20) Fiorano-Fornaci Carani; (21) Savignano; (23) Casa Querciolaia; (24) Ripabianca di Monterado; (25) Castagneto Carducci; and (26) Fontino Cave. (Map Data: Google Earth Pro 7.3, Data SIO, NOAA, U.S. Navy, NGA, GEBCO; Image Landsat/Copernicus, elaboration by A. Vassanelli). 
productions of Favella della Corte, although part of the earliest Impressed Pottery Groups of the southeast, show the absence of some peculiar stylistic features in the decoration such as the rocker pattern. The latter is also missing in the archeological contexts of the Tyrrhenian coast.

Shaped beads in the central-Adriatic area are rare but are enough to underline a difference between the two sides of the Apennine. The earliest specimens, in fact, are made from the shell and bone (Torre Sabea and Colle Santo Stefano). The stone items of Villaggio Rossi are more recent, and the evidence at Ripabianca di Monterado must be referred to exchanges with the central-northern Tyrrhenian area. Significant steatite outcrops, in fact, are in the ophiolitic masses of the northern Apennines mountain range.

In the north of Italy, although scarce, the stone beads production (Monte Alfeo-Godiasco, Riparo Gaban, Sammardenchia, Edera Cave) seems to be attributable to local productions.

Shell and bone discoid and bottle beads are disseminated throughout the whole peninsula, but along the Tyrrhenian area, these items are always associated with the stone ones, while, as pointed earlier, right through the rest of the peninsula, they often represent the only shaped types.

The chronological and geographical framework presented above shows that with the neolithization the shaped beads spread throughout the peninsula as a new "model" of ornament, rich in significance. Possibly as a vehicle for communication: a symbol of identity or social status, or as a simple "modern way" used by people to adorn themselves. This model, over time, has been absorbed and reworked with different raw materials, probably most related to the local habits. Similar considerations can be offered for the bracelets, differently transposed in the Italian territory. The occurrences of stone ring bracelets are mainly distributed in the northern area of the peninsula; however, items in the south have been found that were made from the shell and bone (Ripatetta and Torre Sabea), with radiometric dates earlier than those of the stone ones found in the north. This leads us to consider the first arrival of this type of ornament in the south, where, however, it remains a sporadic presence. On the contrary from around $5700 \mathrm{cal} \mathrm{BC} \mathrm{(Figure} \mathrm{7,} \mathrm{Table} \mathrm{1)}$ onward, the item was largely employed in the north as indicated by the numerous bracelets made of stone and hard animal matter collected (Ca' Bissara, Isorella-Cascina Bocche, Fiorano-Fornaci Carani; Figure 7c and d).

To date, the only elaborate pendant has been found at Colle Santo Stefano, and the other evidence consists of minimally processed items, obtained by local raw materials. Literature about symbolic values often points out the importance of color instead of the raw material. The choice to create this pendant with actinolite, perhaps accidentally recovered, was embedding not only an esthetic value but probably also a symbolic message that the maker intended to transmit. In northern Italy, a similar choice is inferred from the ring bracelets, mostly produced from green stones. Many ethnographic and anthropological studies suggest that in ancient times great importance could be attributed to green color and surfaces that shined. These characteristics could symbolize water, a fundamental nourishment element for plants and crops, hence a clear reminder of the fertility (Bar-Yosef Mayer \& Porat, 2008; Bar-Yosef Mayer, 2019). Rituals recalling fertility at Colle Santo Stefano are distinctly shown by a circular pit surrounded by pebbles, containing a zoomorphic vase (Radi \& Petrinelli Pannocchia, 2018). We might use this interpretative key to link the pendant from Colle Santo Stefano with the feminine sphere and extrapolate from this that it was designed for a female member of the group. In the Adriatic area, the choice of green color rocks for pendant production also seems to be prevalent during the middle Neolithic.

The middle Neolithic Square Mouth Pottery society of northern Italy (Bernabò Brea, 1946; Barfield, 1972; Bagolini \& Biagi, 1977; Bernabò Brea et al., 2010; Del Lucchese \& Starnini, 2015; Laviosa Zambotti, 1943; Maggi, Starnini, \& Voytek, 1997) shows, on the contrary, a change in the conceptualization of personal ornaments in favor of shaped beads and pendants manufactured from black steatite, which become an identity element of distinction among these communities (Mazzieri \& Micheli, 2014; Micheli, 2014). In the same period, in the central-Tyrrhenian area, the use of steatite ornaments increases, probably due to the influence of northern cultures, but without a specific color preference.

Data show that the ornamental items were important aspects of life in every early Neolithic community that spent time and energy producing non-utilitarian objects to materialize their social and ideological beliefs (Bains, 2012). The ornaments have been found almost exclusively in residential areas; burials from this period are scarcely attested and grave goods are poor or not properly linked with single inhumations 
(Continenza Cave and Mora Cavorso Cave). Although this lack of information does not allow the reconstruction of an exhaustive framework about a possible division of the ornaments by gender or age, these items were clearly linked to the everyday life and status of the individuals. To wear an ornament was a way to emphasize their own uniqueness and identity (Hodder, 1986), as a single individual or part of a specific ethnicity. Results show that, from the beginning of the Neolithic, the sharing of similar choices between individuals and groups determined the emergence of symbolic languages having specific geographical distributions, almost in accordance with the results from lithic and pottery studies (Figure 7). The use of shaped beads seems to be principally related to Impressed and Cardial Groups, with significant differences in raw materials and quantity between the south-west (numerous and made principally in stone) and the south-east part of the peninsula (numerically scarce and made predominantly with hard animal materials). Considering the dense exchange network testified by other categories of artifacts, this difference cannot be attributed to the lack of raw materials but rather to specific cultural choices. Bracelets are a primary production of the north, a symbol shared between the different groups that constitute the articulate cultural picture of the earliest Neolithic of this area (Figure 7c and d). This shared symbol attests to a cohesion that perhaps can be seen as a precursor of a collective identity that will subsequently develop in the middle Neolithic.

Conflict of interest: The authors state no conflict of interest.

\section{References}

Alessio, M., Bella, F., Improta, S., Belluomini, G., Cortesi, C., \& Turi, B. (1970). University of Rome carbon-14 dates VIII. Radiocarbon, 12(2), 599-616. doi: 10.1017/S0033822200058677.

Alessio, M., Allegri, L., Bella, F., Broglio, A., Calderoni, G., Cortesi, C., ... Turi B. (1984). 14C datings of three mesolithic series of Trento Basin in the Adige Valley (Vatte di Zambana, Pradestel, Romagnano) and comparisons with mesolithic series of other regions. Preistoria Alpina, 19, 245-254.

Alessio, M., Allegri, L., Ferrari, A., Improta, S., \& Pessina, A. (1996). Nuovi dati di cronologia sulle prime comunità neolitiche dell'Italia nordorientale. Gortania, 17, 37-55.

Amadei, A., \& Grifoni Cremonesi, R. (1986-1987). La Grotta all’Onda, revisione ed inquadramento dei materiali. Rassegna di archeologia, 6, 171-216.

Arobba, D., Panelli, C., Caramiello, R., Gabriele, M., \& Maggi, R. (2017). Cereal remains, plant impressions and $14 \mathrm{C}$ direct dating from the Neolithic pottery of Arene Candide Cave (Finale Ligure, NW Italy). Journal of Archaeological Science, Reports, 12, 395-404. doi: 10.1016/j.jasrep.2017.02.015.

Astuti, P., Bisconti, M., Chiarenza, N., \& Grifoni Cremonesi, R. (2006). Evidenze di circolazione di elementi ornamentali preparati su conchiglie marine dal Paleolitico Superiore e dal Mesolitico della Grotta Continenza, Trasacco (L’Aquila). In Materie prime e scambi nella Preistoria italiana, Atti XXXIX Riunione Scientifica Istituto Italiano di Preistoria e Protostoria (pp. 855-864). Firenze: Istituto Italiano di Preistoria e Protostoria.

Aurino, P., \& Mancusi, V. G. (2016). Valore d'uso e valore d'ornamento: L'ostentazione dello status attraverso l'uso delle asce pendenti nell'Italia neolitica ed eneolitica. Atti del XII incontro di studi di Preistoria e Protostoria in Etruria (pp. 111-128). Firenze: Istituto Italiano di Preistoria e Protostoria.

Bagolini, B. (1980a). Riparo Gaban. Preistoria ed evoluzione dell'ambiente. Trento: Edizioni didattiche del Museo Tridentino di Scienze Naturali.

Bagolini, B. (1980b). Introduzione al Neolitico dell'Italia settentrionale. Pordenone: Società dei Naturalisti Silvia Zenari.

Bagolini, B. (1990). Cultura dei vasi a bocca quadrata il sepolcreto neolitico de La Vela di Trento. In Die ersten Bauer: Pfahlbaufunde Europas, 2 (pp. 225-231). Catalogo Mostra. Zürich: Schweizerisches Landesmuseum.

Bagolini, B., \& Biagi, P. (1977). Current culture history issues in the study of the Neolithic of Northern Italy. Bulletin of the Institute of Archaeology, 14, 143-166.

Bagolini, B., \& Von Eles, P. (1978). L'insediamento neolitico di Imola e la corrente culturale della ceramica impressa nel medio e alto Adriatico. Preistoria Alpina, 14, 33-63.

Bains, R. K. (2012). The social significance of Neolithic stone bead technologies at Çatalhöyük. (PhD thesis). University College London, London. Retrieved from https://discovery.ucl.ac.uk/id/eprint/1368215/

Baioni, M., \& Starnini, E. (2008). La Via Della "Pietra Verde". Il territorio di Piadena tra Neolitico ed Età del Bronzo. In M. Baioni \& C. Fredella (Eds.), Achaeotrade antichi commerci in Lombardia orientale (pp. 89-102). Milano: ETIS. 
Barfield, L. H. (1972). The first Neolithic Cultures of north eastern Italy. In H. Schwabedissen (Ed.), Die Anfänge des Neolithikums vom Orient bis Nordeuropa (Fundamenta A3, pp. 182-216). Westliches Mittelmeergebiet und Britische Inseln. Cologne: Böhlau Verlag.

Bar-Yosef Mayer, D. E. (2019). The colour of ornaments in the Neolithic and Chalcolithic of the Levant: Their symbolic meaning and economic value. In S. Thavapalan \& D. A. Warburton (Eds.), The value of colour: Material and economic aspects in the ancient world (Berlin Studies of Ancient World, 70, pp. 69-97). Berlin: Topoi Edition. doi: 10.17171/3-70.

Bar-Yosef Mayer, D. E, \& Porat, N. (2008). Green stone beads at the dawn of agriculture. PNAS, 105(25), 8548-8551. doi: $10.1073 /$ pnas.0709931105.

Baysal, E. L. (2013). A tale of two assemblages: Early Neolithic manufacture and use of beads in the Konya plain. Anatolian Studies, 63, 1-15. doi: 10.1017/S006615461300001X00001X.

Baysal, E. L. (2019). Personal ornaments in prehistory: An exploration of body augmentation from the Palaeolithic to the early bronze age. Oxford: Oxbow. doi: 10.1080/00665983.2020.1736825.

Belluomini, G. (1981). Direct aspartic acid racemization dating of human bones from archaeological site of Central and Southern Italy. Archaeometry, 23, 125-137. doi: 10.1111/j.1475-4754.1981.tb00302.x.

Benini Accorsi, C. (1974). Le Conchiglie lavorate dell'epigravettiano evoluto del Riparo Tagliente. Memorie del Museo Civico di Storia Naturale di Verona, 20, 405-411.

Bernabò Brea, L. (Ed.). (1946). Gli scavi nella caverna delle Arene Candide, Parte I, Gli strati con ceramiche, scavi $1940-1942$. Collezione di monografie preistoriche ed archeologiche. Bordighera: Istituto Internazionale di Studi Liguri.

Bernabò Brea, L. (Ed.). (1956). Gli scavi nella caverna delle Arene Candide (Finale Ligure). Parte I, Vol. 2: Campagne di scavo 1948-1950. Collezione di monografie preistoriche ed archeologiche. Bordighera: Istituto Internazionale di Studi Liguri.

Bernabò Brea, M., Maffi, M., Mazzieri, P., \& Salvadei, L. (2010). Testimonianze funerarie della gente dei Vasi a Bocca Quadrata in Emilia occidentale. Archeologia e antropologia. Rivista di Scienze Preistoriche, LX, 63-126.

Bertola, S., Broglio, A., Cassoli, P., Cilli, C., Cusinato, A., Dalmeri, G., ... Ziggiotti, S. (2007). L'Epigravettiano recente nell'area prealpina e alpina orientale. In F. Martini (Ed.), L'Italia tra 15.000 e 10.000 anni fa. Cosmopolitismo e regionalità nel Tardoglaciale. Atti della Tavola Rotonda 2005 (Millenni, Studi di Archeologia preistorica, pp. 39-94). Firenze: Museo Fiorentino di Preistoria.

Bertola, S., Broglio, A., Cristiani, E., De Stefani, M., Gurioli, F., Negrino, F., ... Vanhaeren, M. (2013). La diffusione del primo Aurignaziano a sud dell'arco alpino. Preistoria Alpina, 47, 123-152.

Bertolini, M., Cristiani, E., Modolo, M., Visentin, P., \& Romandini, M. (2016). Late Epigravettian and Mesolithic foragers of the eastern Alpine region: Animal exploration and ornamental strategies at Riparo Brianzo (Northern Italy). Quaternary International, 423, 73-91. doi: 10.1016/j.quaint.2015.09.083.

Biagi, P. (1979). Stazione neolitica a Ostiano (CR), località Dugali Alti: Scavi 1980. Preistoria Alpina, 14, 25-38.

Biagi, P. (1995). L'insediamento neolitico di Ostiano-Dugali Alti (Cremona) nel suo contesto ambientale ed economico. Monografie di Natura Bresciana, 22. Brescia: Natura Bresciana.

Biagi, P. (2003). New data on the Early Neolithic of the upper adriatic. In L. Nikolova (Ed.), Early symbolic systems for communication in Southeast Europe (BAR, International Series, 1139, pp. 337-348). Oxford: Bar Publishing.

Biagi, P., \& Nisbet, R. (1987). The earliest farming communities in northern Italy. In J. Guilaine, J. Courtin, J.-L. Roudil, \& J.-L. Vernet (Eds.), Premières communautés paysannes en Méditerranée occidentale (pp. 447-453). Paris: Historie.

Biagi, P., Starnini, E., \& Voytek, B. A. (1993). The Late Mesolithic and Early Neolithic settlement of northern Italy: Recent considerations. Porocilo o Raziskovanju Paleolita, Neolita in Eneolita v Sloveniji (Ljubljana), XXI, 45-67.

Biagi, P., Starnini, E., \& Voytek, B. A. (2008). The Mesolithic-Neolithic transition in the Trieste Karst (north-eastern Italy) as seen from the excavations at the Edera Cave. The Iron Gates in Prehistory: New perspectives (BAR, International Series, 1893, pp. 251-260). Oxford: BAR Publishing. doi: 10.30861/9781407303734.

Biagi, P., Starnini, E., Boric, D., \& Mazzucco, N. (2020). Early Neolithic settlement of the Po Plain (northern Italy): Vhò and related sites. Documenta Praehistorica, XLVII, 192-221. doi: 10.4312\dp.47.11.

Biagi, P., \& Starnini, E. (2021). L’Arma dell’Aquila a Finale Ligure (Savona): L'occupazione della Cultura della Ceramica Impressa nel quadro del Neolitico antico dell'alto Tirreno. In R. Cicilloni \& C. Lugliè (Eds.), Mediterranea. Studi e ricerche di preistoria e protostoria in onore di Giuseppa Tanda (pp. 47-54). Perugia: Morlacchi Ed.

Binder, D., \& Maggi, R. (2001). Le Néolithique ancien de l'arc liguro-provençal. Bulletin de la Société Préhistorique Française, 98(3), 411-422. doi: 10.3406/galip.1994.2127.

Binder, D., Lanos, Ph., Angeli, L., Gomart, L., Guilaine, J., Manen, ... Thiebault, S. (2017). Modelling the Earliest North-Western dispersal of the Mediterranean Impressed wares: New dates en Bayesian chronicles. Documenta Praehistorica, XLIV, 54-77. doi: 10.4312/dp.44.4.

Bisconti, M., \& Zamagni, B. (2007). Elementi di parure e pseudomanufatti da Cala Giovanna Piano: Conchiglie, pietra e osso. In C. Tozzi \& M. C. Weiss (Eds.), Preistoria e protostoria dell'area tirrenica. Corsica e Sardegna (Interreg III A Francia - Italia "Isole" Toscana, Corsica, Sardegna Asse III, pp. 135-143). Pisa: Felici Editore.

Borrello, M. (2005). Le conchiglie nella preistoria e nella protostoria. In Borrello M. A. (Ed.), Conchiglie e archeologia (Preistoria Alpina, 40(Suppl. 1), pp. 19-42). Trento: Museo delle Scienze.

Borrello, M. A., \& Dalmeri, G. (2005). Gli ornamenti preistorici lavorati in conchiglie conservati presso il Museo Tridentino di Scienze Naturali. In M. A. Borrello (Ed.), Conchiglie e archeologia (Preistoria Alpina, 40(Suppl. 1), pp. 43-52). Trento: Museo delle Scienze. 
Borrello, M. A., \& Micheli, R. (2005). Gli ornamenti in conchiglia del Neolitico dell'arco alpino. Determinazione, provenienza, tecnologia e cronologia. Nota preliminare. In G. Malerba \& P. Visentini (Eds.), Atti del $4^{\circ}$ convegno nazionale di archeozoologia (Quaderni del Museo Archeologico del Friuli Occidentale, 6, pp. 149-159). Pordenone: Museo Archeologico del Friuli Occidentale.

Borrello, M. A., \& Rossi, G. (2005). La lavorazione di ornamenti in Spondylus gaederopus nel Neolitico della caverna delle Arene Candide (Savona, Italia). Nota preliminare. In M. A. Borrello (Ed.), Conchiglie e Archeologia (Preistoria Alpina, 40(Suppl. 1), pp. 83-90). Trento: Museo delle Scienze.

Boschian, G. (1989). Un nuovo dato di cronologia assoluta nel quadro culturale del Mesolitico e del Primo Neolitico del Carso triestino. Atti Civici Musei di Storia e Arte di Trieste (pp. 49-56). Trieste: Civici Musei di Storia e Arte.

Boschian, G., Caponi, G., Colombo, M., \& Gabriele, M. (2005). Campo nell'Elba (LI): Isola di Pianosa: Gli scavi nell'insediamento neolitico di Cala Giovanna Piano. Notiziario della Soprintendenza per i Beni Archeologici della Toscana, 1, 399-400.

Brandaglia, M. (1987). Il neolitico a ceramica impressa dell'isola del Giglio. L'industria litica. Studi per l'ecologia del Quaternario, 9, 51-61.

Broglio, A. (1984). Paleolitico e mesolitico. In S. Aspes (Ed.), Il Veneto nell'Antichità - Preistoria e protostoria, 1 (pp. 161-311). Verona: Banca Popolare di Verona.

Broglio, A. (1995). Discontinuità tra Musteriano e Protoaurignaziano mediterraneo nella grotta di Fumane (Monti Lessini, Prealpi Venete). Veleia, 12, 49-65.

Broglio, A. (1997). Gli oggetti ornamentali dei cacciatori- raccoglitori della preistoria. In L. Endrizzi \& F. Marzatico (Eds.), Ori delle Alpi (Quaderni della Sezione Archeologica, 6, pp. 161-166). Trento: Ufficio Beni Archeologici della Provincia Autonoma di Trento.

Calattini, M. (2005). Il livello dell'Epigravettiano finale di Grotta delle Mura (Bari)-Area A. In Askategi, miscellanea in memoria di Georges Laplace (Rivista di Scienze Preistoriche (Suppl. 1), pp. 305-320). Firenze: Istituto Italiano di Preistoria e Protostoria.

Carboni, G., \& Anzidei, A. P. (2020). Casali di porta Medaglia (Roma). In A. P. Anzidei \& G. Carboni (Eds.), Roma prima del mito: Abitati e necropoli dal neolitico alla prima eta' dei metalli nel territorio di Roma (VI-III millennio a.C.) (pp. 163-167). Oxford, Archaeopress Publishing.

Colombo, M., \& Tozzi, C. (2007). Le nuove ricerche a Pianosa: Gli scavi dal 2003 al 2006. In C. Tozzi \& M. C. Weiss (Eds.), Préhistoire et protohistoire de l'aire tyrrhénienne (pp. 75-87). Pisa: Felici Editore.

Colombo, M., \& Serradimigni, M. (2016). Presenza e distribuzione degli elementi di ornamento a Grotta Continenza (Trasacco - AQ). In Il Fucino e le aree limitrofe nell' Antichità, Atti del IV convegno di archeologia (pp. 109-114). Avezzano: DVG Studio.

Costantini, L., \& Stancanelli, M. (1994). La preistoria agricola dell'Italia centro-meridionale: Il contributo delle indagini archeobotaniche. Origini, 18, 149-244.

Cremonesi, G. (1976). Industrie litiche, neolitiche ed eneolitiche da località varie del Materano. In Il museo nazionale ridola di matera (pp. 77-79). Matera: Soprintendenza Archeologica della Basilicata.

Cremonesi, G. (1987). Due complessi d'arte del Paleolitico superiore: La Grotta Polesini e la Grotta delle Veneri. Atti della XXV riunione scientifica dell'Istituto Italiano di preistoria e protostoria (pp. 35-45). Firenze: Istituto Italiano di Preistoria e Protostoria.

Cremonesi, G., Guilaine, J., Barbaza, M., Coularou, J., Fonto, O., Grifoni, R., \& Vaquer, J. (1987). L'habitat de Torre Sabea (Gallipoli, Puglia) dans le cadre du Néolithique ancien de l'Italie du sud-est. In J. Guilaine, J. Courtin, J.-L. Roudil, \& J.-L. Vernet (Eds.), Premières communautés paysannes en Méditerranée occidentale (pp. 377-385). Paris: Historie.

Cristiani, E. (2012). Ornamental traditions of the late Pleistocene and the early Holocene foragers in the eastern Alps: The case of Riparo Biarzo. Gortania, 34, 89-102.

Dalmeri, G., \& Lanzinger, M. (1997). Gli oggetti d'ornamento del Trentino-Alto Adige di età Paleolitica- Mesolitica. In L. Endrizzi \& F. Marzatico (Eds.), Ori delle Alpi, catalogo della mostra (Quaderni della Sezione Archeologica, 6, pp. 403-404). Trento: Ufficio Beni Archeologici della Provincia Autonoma di Trento.

D’Amico, C., \& Ghedini, M. (1996). La pietra levigata della collezione «Traverso» di Alba, nel Museo etnografico «L. Pigorini» di Roma. Museologia Scientifica, 13(Suppl. 1-2), 293-312.

D’Amico, C. (1998). La circolazione delle materie prime nel Neolitico: Le pietre verdi. In A. Pessina \& G. Muscio (Eds.), Settemila anni fa il primo pane: Ambiente e culture delle società neolitiche (pp. 177-183). Udine: Museo Friulano di Storia Naturale.

D’Amico, C., Starnini, E., \& Voytek, B. A. (2000). L'industria litica di Brignano Frascata (AL): Dati paleoeconomici di un insediamento del Neolitico Antico attraverso l'analisi tipologica, funzionale e lo studio della provenienza delle materie prime. Preistoria Alpina, 31(1995), 91-124.

Dal Ri, L. (1996). Villandro, loc. Plunacker. In M. Venturino Gambari (Ed.), Le vie della pietra verde. L'industria litica levigata nella preistoria dell'Italia settentrionale Catalogo della mostra (pp. 91-92). Torino Museo delle Antichità. Alba: Edizioni Omega.

Del Lucchese, A., \& Starnini, E. (2015). Aggiornamenti sulla fase antica della Cultura dei Vasi a Bocca Quadrata in Liguria, da una revisione dei materiali ceramici in corso, Archeologia in Liguria, V(2012-2013), 27-37.

Delpino, C. (2020). Il Neolitico antico dell'areale medio-tirrenico: Gli aspetti della ceramica impressa e della ceramica lineare nel Lazio e nel territorio di Roma. In A. P. Anzidei \& G. Carboni (Eds.), Roma prima del mito. Abitati e necropoli dal Neolitico alla prima età dei metalli nel territorio di Roma (VI-III mill. a.C.) (pp. 3-24). Oxford: Archaeopress. 
Ducci, S., Guerrini, M. V., \& Perazzi, P. (2000). L'insediamento della Scola (Isola di Pianosa, Comune di Campo nell'Elba, LI). In C. Tozzi \& M. C. Weiss (Eds.), Il primo popolamento olocenico dell'area corso-toscana (Interreg II Toscana-Corsica, pp. 83-90). Pisa: ETS.

Fabbri, C., \& Angeli, L. (2010). Premiers résultats de l'étude des productions céramiques du Néolithique ancien: L'exemple de deux sites à céramique imprimée du versant adriatique italien. In C. Manen, F. Convertini, D. Binder, \& I. Senepart (Eds.), Premières sociétés paysannes de Méditerranée occidentale. Structures des productions céramiques (pp. 81-87). Paris: Société Préhistorique Française.

Fontana, F., Guerreschi, A., Bertola, S., Cremona, M. G., Cavulli, F., Falceri, L., ... Visentin, D. (2015). I livelli più antichi della serie epigravettiana "interna" di Riparo Tagliente: sfruttamento delle risorse litiche e sistemi tecnici. In G. Leonardi \& V. Tinè (Eds.), Atti della XLVIII Riunione Scientifica dell'Istituto Italiano di Preistoria e Protostoria (pp. 43-53). Firenze: Istituto Italiano di Preistoria e Protostoria.

Formicola, V. (1988). The triplex burial of Barma Grande (Grimaldi, Italy). Homo, 39, 130-143.

Fugazzola Delpino, M. A. (2002). La Marmotta. In M. A. Fugazzola Delpino, A. Pessina, \& V. Tiné (Eds.), Le ceramiche impresse del Neolitico antico. Italia e Mediterraneo (Collana di Studi di Paletnologia Italiana, 1, pp. 97-116). Roma: Istituto Poligrafico e Zecca dello Stato.

Fugazzola Delpino, M. A., D'Eugenio, G., \& Pessina, A. (1999). Le Néolithique ancien et moyen de l'Italie centro-occidentale. In J. Vaquer (Ed.), Le Néolithique du nord-ouest méditerranéen, Actes du XXIV Congrès Préhistorique de France (pp. 25-34). Paris: Société Préhistorique Française.

Franco, C. (2011). La fine del Mesolitico in Italia. Identità culturale e distribuzione territoriale degli ultimi cacciatori-raccoglitori. In P. Biagi (Ed.), Società per la Preistoria e la Protostoria della regione Friuli Venezia Giulia, Quaderno 13. Trieste: Museo Civico di Storia Naturale.

Geniola, A. (1982). Marcianese. Il villaggio Rossi, entità del Neolitico medio arcaico abruzzese. Rapporto di scavo. Lanciano: Itinerari Lanciano editore.

Giuggiola, O., Imperiale, G., Lamberti, A., Piacentino, G., \& Vicino, G. (1966). Un rifugio del Neolitico Medio nel Finalese: L'arma delle Anime. Rivista di Studi Liguri, XXXII(1-2), 106-142.

Graniti, M. (2008). Gli oggetti di parure del villaggio neolitico di Colle Santo Stefano. (Unpublished BA thesis). University of Pisa, Pisa.

Grifoni Cremonesi, R., Serradimigni, M., \& Usala, M. (2011). Le campagne di scavo dal 2001 al 2009 nella Grotta Continenza di Trasacco (AQ). I livelli dell'Epigravettiano finale, del Mesolitico e del Neolitico antico. In /l Fucino e le aree limitrofe nell'antichità, Atti del III Convegno di Archeologia (pp. 27-39). Avezzano: DVG Studio.

Gravina, A. (2014). Mulino Dabbasso, Serra dei Travi, e Toppo Capuana. Tre insediamenti preistorici e protostorici nella media Valle del Fortore. Taras-Rivista di Archeologia, XXXIII/XXXIV(2013/2014), 23-54.

Guilaine, J. A. (2018). A personal view of the neolithisation of the Western Mediterranean. Quaternary International, 470, 211-225. doi: 10.1016/j.quaint.2017.06.019.

Guilaine, J., \& Cremonesi, G. (Eds.). (2003). Torre Sabea: Un etablissement du Neolithique ancien en Salento. Collection de l'Ecole Française de Rome 315. Roma: Ecole Française de Rome. doi: 10.1400/37375.

Guilaine, J., Gasco, J., Evin, J., \& Valladas, H. (2003). Torre Sabea et les données de la chronologie absolue méditerranéenne. In J. Guilaine \& G. Cremonesi (Eds.), Torre Sabea: Un établissement du Néolithique ancien en Salento (pp. 368-373). Roma: Ecole Française de Rome. doi: 10.1400/37375.

Guilaine, J., \& Manen, C. (2007). From Mesolithic to early Neolithic in the western Mediterranean. In A. Whittle \& V. Cummings (Eds.), Going Over: The Mesolithic-Neolithic transition in North-West Europe (Proceedings of the British academy, 144, pp. 21-51). Oxford: Oxford University Press. doi: 10.5871/bacad/9780197264140.001.0001.

Gurioli, F., Cilli, C., Giacobini, G., \& Broglio, A. (2005). Le conchiglie perforate aurignaziane della Grotta di Fumane (VR). In G. Malerba \& P. Visentini (Eds.), Atti del IV convegno nazionale di archeozoologia (Quaderni del Museo Archeologico del Friuli Occidentale, 6, pp. 59-65). Pordenone: Museo Archeologico del Friuli Occidentale.

Hodder, I. (1986). Reading the past: Current approaches to interpretation in archaeology. Cambridge: Cambridge University Press.

Iacopini, A. (2000). Il sito Neolitico di casa querciolaia (Livorno). Rassegna di Archeologia, 17, 127-178.

Improta, S., \& Pessina, A. (1998). La neolitizzazione dell'Italia settentrionale: Il nuovo quadro cronologico. In A. Pessina \& G. Muscio (Eds.), Settemila anni fa il primo pane. Ambienti e Culture delle società neolitiche (pp. 107-115). Udine: Museo Friulano di Storia Naturale.

Kozlowski, S. K., \& Dalmeri, G. (2002). Riparo Gaban: The Mesolithic layers. Preistoria Alpina, 36, 3-42.

Laviosa Zambotti, P. (1943). Le più antiche culture agricole europee. L'Italia, i Balcani e l'Europa centrale durante il Neoeneolitico. Milano: Casa Editrice Giuseppe Principato.

Lollini, D. G. (1991). Museo Archeologico Nazionale delle Marche. Sezione preistorica. Paleolitico-Neolitico. Falconara: Errebi.

Lo Vetro, D., Balducci, C., \& Volante, N. (2007). La Preistoria nel Territorio di Grosseto. In C. Citter \& A. Arnoldus-Huyzendveld (Eds.), Archeologia Urbana a Grosseto. La Città nel Contesto Geografico della Bassa Valle dell'Ombrone; Origine e sviluppo di una Città Medievale Nella “Toscana delle Città Deboli”. Le Ricerche 1997-2005 (pp. 119-130). Firenze: All'Insegna del Giglio. doi: 10.1400/215642. 
Maggi, R. (1997). The radiocarbon chronology. In R. Maggi, E. Starnini, \& B. A. Voytek (Eds.), Arene candide: A functional and environmental assessment of the holocene sequence (Excavations Bernabò Brea-Cardini 1940-1950) (pp. 31-52). Memorie dell'Istituto Italiano di Paleontologia Umana, 5. Roma: Il Calamo.

Maggi, R., Starnini, E., \& Voytek, B. A. (Eds.). (1997). Arene candide: A functional and environmental assessment of the holocene sequence (Excavations Bernabò Brea-Cardini 1940-1950). Memorie dell'Istituto Italiano di Paleontologia Umana, 5. Roma: Il Calamo.

Manen, C., Perrin, T., Guilaine, J., Bouby, L., Bréhard, S., Briois, ... Vigne. J-D. (2019). The Neolithic transition in the Western Mediterranean: A complex and non-linear diffusion process - The radiocarbon record revisited. Radiocarbon, 61(2), 531-571. doi: 10.1017/RDC.2018.98.

Mazzieri, R., \& Micheli, R. (2007). Struttura 11: Resti di un atelier di lavorazione dei vaghi di collana in steatite del Neolitico medio. Padusa, XLIII(2007), 7-23.

Mazzieri, R., \& Micheli, R. (2014). Tradizioni funerarie e ornamenti personali: Alcune osservazioni dalla sfera VBQ emiliana alla luce delle ultime scoperte. In M. Bernabò Brea, A. Manfredini, \& R. Maggi (Eds.), 5000-4300 a.C. Il pieno sviluppo del Neolitico in Italia (Rivista di Studi Liguri, LXXVII-LXXIX, pp. 323-329). Bordighera: Istituto Internazionale di Studi Liguri.

Micheli, R. (2003). Gli ornamenti. In M. A. Fugazzola Delpino, A. Pessina, \& V. Tiné (Eds.), Le ceramiche impresse nel Neolitico antico. Italia e Mediterraneo. Studi di Paletnologia, I (Collana del Bullettino di Paletnologia Italiana, I, pp. 269-288). Roma: Istituto Poligrafico Zecca dello Stato.

Micheli, R. (2005). Ornamenti in conchiglia del Neolitico dell'Italia settentrionale. In M. A. Borrello (Ed.), Conchiglie e Archeologia (Preistoria Alpina, 40(Suppl. 1), pp. 53-70). Trento: Museo delle Scienze.

Micheli, R. (2009). Ornamenti in pietra e terracotta. In V. Tiné (Ed.), Favella-Un villaggio neolitico nella Sibaritide (pp. 417-424). Studi di Paletnologia, III. Roma: Istituto Poligrafico e Zecca dello Stato.

Micheli, R. (2012). Raw materials, personal ornaments and Neolithic groups: Some observations on stone bracelets of the Early Neolithic of northern Italy. In M. Borrell, F. Borrell, J. Bosch, \& M. Molist (Eds.), Networks in the Neolithic. Raw materials, products and ideas circulation in the Western Mediterranean basin (VII-III a.C.) (Rubricatum. Revista del Museu de Gavà, 5 , pp. 241-248). Gavà: Eivissa \& Associats, s.c.c.l.

Micheli, R. (2014). Ornamenti personali e gruppi neolitici: Elementi di differenziazione culturale nel corso del v millennio BC. Potenzialità e problematiche dello studio del costume antico: Il caso dell'Italia settentrionale. In M. Bernabò Brea, A. Manfredini, \& R. Maggi (Eds.), 5000-4300 a.C. Il pieno sviluppo del Neolitico in Italia (Rivista di Studi Liguri, LXXVII-LXXIX, pp. 235-241). Bordighera: Istituto Internazionale di Studi Liguri.

Micheli, R. (2016). Gli ornamenti personali dei gruppi del Neolitico recente in Italia settentrionale: Un problema aperto. In F. M. Gambari, L. Ferrero, \& S. Padovan (Eds.), Pionieri delle Alpi. Il pieno Neolitico tra le Alpi occidentali. In ricordo di Giampiero Guerreschi (Archeologia Piemonte, 5, pp. 65-77). Torino: Ministero dei Beni e delle Attività culturali e del Turismo Soprintendenza Archeologia del Piemonte.

Micheli, R., Panelli, C., Rossi, S., \& Maggi, R. (2018). Ornamenti personali dai livelli Impresso-Cardiali della Caverna delle Arene Candide. Poster presented at the LIII Riunione Scientifica dell'Istituto Italiano di Preitoria e Protostoria. doi: 10.13140/ RG.2.2.13398.50241.

Morter, J., \& Robb, J. (2010). Chora of croton, the Neolithic settlement at Capo Alfiere. Austin: University of Texas Press.

Mottana, A., Crespi, R., \& Liborio, G. (Eds.). (2004). Minerali e rocce. Milano: Mondadori Electa.

Mussi, M. (1991). L’utilisation de la stéatite dans les grottes des Balzi Rossi (ou grottes de Grimaldi). Gallia Préhistoire, 33, 1-16. doi: 10.3406/galip.1991.2283.

Mussi, M., Coubray, S., Giraudi, C., Mazzella, G., Ton Lutti, P., Wilkens, B., \& Zampetti, D. (2000). L'exploitation des Territoires de Montagne dans les Abruzzes (Italie Centrale) Entre Tardiglaciare et Holocène Ancien. Actes de la Table Ronde Epipaléolithique et Mésolithique (Lausanne 21-23 Novembre 1997). Cahiers D’archéologie Romande, 81, 277-284.

Mussi, M., \& Zampetti, D. (1993). Ciottoli decorati e ciottoli utilizzati della fine del Paleolitico a Grotta Polesini. Bullettino di Paletnologia Italiana, 84, 57-83.

Noble, W., \& Davidson, I. (1996). Human evolution, language, and mind: A psychological and archaeological inquiry. London: Cambridge University Press.

Odetti, G. (1990). Saggio nei livelli neolitici della Grotta Pollera. Rivista Ingauna e Intemelia, XLV, 107-142.

Peresani, M., Forte, M., Quaggiotto, E., Colonese, A. C., Romandini, M. C., Cilli, C., \& Giacobini, G. (2019). Special issue: Early personal ornaments - Marine and freshwater shell exploitaiton in the early upper paleolithic: Re-examination of the assemblages from Fumane cave (NE Italy). Paleo Anthropology, 2019, 64-81. doi: 10.4207/PA.2019.ART124.

Perini, M., Starnini, E., D’Amico, C., \& Ottomano, C. (2001). A new settlement of the Vhò Group at Isorella (BS): Preliminary results of the 1997 research. Atti della XXXIII Riunione Scientifica dell'Istituto Italiano di Preistoria e Protostoria, Preistoria e Protostoria del Trentino Alto Adige/Südtirol (Preistoria Alpina, 34(1998), pp. 5-10). Trento: Museo Delle Scienze.

Perrin, T. (2006). Nouvelles Réflexions sur la Transition MésolithiqueRécent - Néolithique Ancien à L’abri Gaban (Trento, Italie). Preistoria Alpina, 41, 89-146.

Petrinelli Pannocchia, C., \& Vassanelli, A. (2016). Il Pendaglio di Colle Santo Stefano, Ortucchio (AQ). In Il Fucino e le aree limitrofe nell' Antichità, Atti del IV Convegno di Archeologia (pp. 109-114). Avezzano: DGV Studio.

Pessina, A. (1993). Un bracciale di età Neolitica da Sammardenchia (UD). Quaderni Friulani di Archeologia, III (Brevi Note), 153-154. 
Pessina, A. (1998). Aspetti culturali e problematiche del primo Neolitico dell'Italia settentrionale. In A. Pessina \& G. Muscio (Eds.), Settemila anni fa il primo pane: Ambiente e culture delle società neolitiche (pp. 95-105). Udine: Museo Friulano di Storia Naturale.

Pessina, A. (2002). Le facies a ceramica impressa dell'area medio-adriatica. In M. A. Fugazzola Delpino, A. Pessina, \& V. Tiné (Eds.), Le ceramiche impresse del Neolitico antico. Italia e Mediterraneo (Studi di paletnologia, I, pp. 117-130). Roma: Istituto Poligrafico e Zecca dello Stato.

Pessina, A., \& Rottoli, M. (1996). New evidence on the earliest farming cultures in Northern Italy: Archaeological and palaeobotanical data. Porocilo o Raziskovanju Paleolita, Neolita in Eneolita v Sloveniji (Ljubljana), XXIII, 77-103.

Pessina, A., \& Tiné, V. (2008). Archeologia del Neolitico. L'Italia tra il VI e il IV millennio a.C. Roma: Carrocci Ed.

Puglisi, S. M. (1955). L'industria microlitica nei livelli a ceramica impressa di Coppa Nevigata. Rivista di Scienze Preistoriche, $X, 19-37$.

Radi, G. (1980). Resti di un villaggio neolitico a Villa Badessa (Pescara). Atti della Società Toscana di Scienze Naturali, Memorie, LXXXVI (1979, serie A), 405-414.

Radi, G. (2003). Gli oggetti di ornamento. In J. Guilaine \& G. Cremonesi (Eds.), Torre Sabea: Un établissement du néolithique ancien en Salento (pp. 209-217). Rome: École Française de Rome. doi: 10.1400/37375.

Radi, G. (2010). Les sequences de la ceramique imprimee en Italie. In C. Manen, F. Convertini, D. Binder, \& I. Sénépart (Eds.), Premières sociétés paysannes de Méditerranée occidentale. Structures des productions céramiques, séance spécialisée de la Société préhistorique française (memoire LI, pp. 133-147). Paris: Société Préhistorique Française.

Radi, G., Boschian, G., Calani, L., Pistoia, A. R., \& Zamagni, B. (2001). Nuovi dati dal villaggio a ceramica impressa di Colle S. Stefano (Ortucchio). In Il Fucino e le aree limitrofe nell'antichità, Atti del Il convegno di Archoelogia (pp. 70-81). Avezzano: DVG Studio.

Radi, G., \& Petrinelli Pannocchia, C. (2018). The beginning of the Neolithic Era in Central Italy. Quaternary International, 470, 270-284.

Radmilli, A. M. (1974). Popoli e civiltà dell'Italia antica. I. Roma: Società Romana di Storia Patria.

Reimer, P. J., Austin, W. E. N., Bard, E., Bayliss, A., Blackwell, P. G., Bronk Ramsey, C., ... S. (2020). The IntCal20 Northern hemisphere radiocarbon age calibration curve (0-55 cal kBP). Radiocarbon, 62, 725-757. doi: 10.1017/RDC.2020.41.

Ribero, M. (2017). Anelloni litici italiani: Aggiornamenti e nuove proposte interpretative a quaranta anni dalle prime ricerche. Rivista di Scienze Preistoriche, LXVII, 111-144.

Rigaud, S., D’Errico, F., \& Vanhaeren, M. (2015). Ornaments reveal resistance of North European cultures to the spread of farming. PLoS One, 10(4), e0121166. doi: 10.1371/journal.pone.0121166.

Roach-Higgins, M., \& Eicher, J. (1992). Dress and identity. Clothing and Textiles Research Journal, 10(4), 1-8.

Ronchitelli, A., Mugnaini, S., Arrighi, S., Atrei, A., Capecchi, G., Giamello, M., ... Moroni, A. (2015). When technology joins symbolic behaviour: The Gravettian Burials at Grotta Paglicci (Rignano Garganico e Foggia e Southern Italy). Quaternary International, 359-360, 423-441. doi: 10.1016/j.quaint.2014.08.038.

Sammartino, F. (2007). Gli insediamenti neolitici di Castagneto Carducci (Livorno). In C. Tozzi \& M. C. Weiss (Eds.), Préhistoire et protohistoire de l'aire tyrrhénienne (Interreg III A Francia - Italia "Isole" Toscana, Corsica, Sardegna Asse III, pp. 203-208). Pisa: Felici Editore.

Shennan, S., Downey, S. S., \& Timpson, A. (2013). Regional population collapse followed initial agriculture booms in midHolocene Europe. Nature Communications, 4, 2486. doi: 10.1038/ncomms3486.

Silvestri, L., Achino, K. F., Gatta, M., Rolfo, M. F., \& Salari, L. (2020). Grotta Mora Cavorso: Physical, material and symbolic boundaries of life and death practices in a Neolithic cave of central Italy. Quaternary International, 53, 29-38. doi: 10.1016/j.quaint.2018.09.050.

Simone Zopfi, L. (2004). La neolitizzazione nell'Oltrepò pavese. In M. Venturino Gambari (Ed.), Alla conquista dell'appennino. Le prime comunità delle valli Curone, Grue e Ossona (pp. 89-94). Torino: Omega Edizioni.

Skeates, R. (1994). A radiocarbon date-list for prehistoric Italy (c. 46,400 BP-2450/400 cal BC). In R. Skeates \& R. D. Whitehouse (Eds.), Radiocarbon dating and Italian prehistory (pp. 147-288). London: Accordia Research Centre and The British School at Rome.

Skeates, R. (2004). New radiocarbon dates for prehistoric Italy. Supplementary list 5. The Accordia Research Papers, 9 (2001-2003), 163-181.

Skeates, R., \& Whitehouse, R. D. (1999). New radiocarbon dates for prehistoric Italy 3. The Accordia Research Papers, 7 (1997-1998), 149-162.

Starnini, E. (1998). Nuovi dati sul gruppo culturale del Vhò dagli scavi dell'insediamento di Isorella (Brescia). Natura Bresciana, 31, 229-244.

Starnini, E. (1999). Industria litica scheggiata. In S. Tiné, (Ed.), Il Neolitico nella caverna delle arene candide (Scavi 1972-1977) (Collezione di Monografie Preistoriche ed Archeologiche X, pp. 219-236 and pp. 450-471). Bordighera: Istituto Internazionale di Studi Liguri.

Starnini, E., \& Voytek, B. A. (1997). New light on old stones: the ground stone assemblage from the Bernabò Brea excavation at Arene Candide. In R. Maggi, E. Starnini, \& B. Voytek (Eds.), Arene Candide: a functional and environmental assessment of the Holocene sequence excavated by L. Bernabò Brea (1940-50) (Monografie dell'Istituto Italiano di Paleontologia Umana, Nuova Serie 5, pp. 427-511). Roma: Istituto Italiano di Paleontologia Umana. 
Starnini, E., Biagi, P., \& Mazzucco, N. (2018). The beginning of the Neolithic in the Po Plain (northern Italy): Problems and perspectives. Quaternary International, 470, 301-317.

Starnini, E., Ghisotti, F., Girod, A., \& Nisbet, R. (2000). Nuovi dati sul Neolitico antico della Pianura Padana centrale dal sito di Isorella (Brescia). In A. Pessina \& G. Muscio (Eds.), La Neolitizzazione tra oriente e occidente, atti del convegno di studi (pp. 231-255). Udine: Museo Friulano di Storia Naturale.

Stiner, M. C., Kuhn, S. L., \& Güleç, E. (2013). Early upper Paleolithic shell beads at Uçagizli Cave I (Turkey): Technology and the socioeconomic context of ornament life-histories. Journal of Human Evolution, 64(5), 380-398. doi: 10.1016/ j.jhevol.2013.01.008.

Tanda, G. (1977). Gli anelloni litici italiani. Preistoria Alpina, 13, 111-155.

Tiné, S. (1974). Il Neolitico e l'Età del Bronzo della Liguria alla luce delle recenti scoperte. Atti della XVI riunione scientifica dell'istituto italiano di preistoria e protostoria (pp. 37-52). Firenze: Istituto Italiano di Preistoria e Protostoria.

Tiné, S. (1983). Passo di Corvo e la civiltà neolitica del Tavoliere. Genova: Sagep.

Tiné, V. (2009). Favella: Un villaggio neolitico nella Sibaritide. Roma: Istituto Poligrafico e Zecca dello stato.

Tozzi, C. (1996). Tradizione mesolitica. Grotta Marisa, Grotta Continenza e Latronico 3. In V. Tiné (Ed.), Atti seminario internazionale, Rossano Calabro, I (pp. 53-59). Rossano: Rubbettino Editore.

Traversone, B. (1999). Le parures. In S. Tiné (Ed.), Il Neolitico nella Caverna delle Arene Candide (scavi 1972-1977) (Collezione di monografie preistoriche e archeologiche X, pp. 283-298 and pp. 518-533, p. 580). Bordighera: Istituto Internazionale di Studi Liguri.

Ucelli Gnesutta, P., Boschian, G., Cantoro, G., Castiglioni, E., Dini, M., Maspero, A., ... Rottoli., M. (2006). I livelli epigravettiani della Grotta delle Settecannelle (Viterbo). Rivista di Scienze Preistoriche, LVI, 127-184.

Vanhaeren, M., \& D’Errico, F. (2006). Aurignacian Ethno-linguistic geography of Europe revealed by personal ornaments. Journal of Archaeological Science, 33, 1105-1128. doi: 10.1016/j.jas.2005.11.017.

Vassanelli, A. (2018). Tra Simbolo e Funzione: I manufatti in steatite di età pre protostorica del Territorio Livornese. (Unpublished MA thesis). University of Pisa, Pisa.

Venturino Gambari, M., \& Motella De Carlo, S. (1995). Le datazioni radiometriche. In M. Venturino Gambari (Ed.), Navigatori e contadini. Alba e la valle del Tanaro nella Preistoria (Quaderni della Soprintendenza Archeologica del Piemonte, Monografie, Vol. 4, pp. 271-272). Torino: Edizioni dell'Orso.

Zamagni, B. (1996). Brignano Frascata. In M. Venturino Gambari (Ed.), Le vie della pietra verde. L' industria litica levigata nella preistoria dell'Italia settentrionale (pp. 79-84). Torino: Omega Edizioni.

Zamagni, B. (2003). Gli oggetti d'ornamento. In C. Tozzi \& B. Zamagni (Eds.), Gli scavi nel villaggio neolitico di Catignano (1971-1980) (Origini, pp. 213-215). Firenze: Istituto Italiano di Preistoria e Protostoria.

Zamagni, B. (2006). Gli ornamenti su conchiglia dal sito neolitico di Ripa Tetta (Foggia). In Materie prime e scambi nella preistoria Italiana, Atti XXXIX Riunione Scientifica Istituto Italiano di preistoria e protostoria (pp. 975-978). Firenze: Istituto Italiano di Preistoria e Protostoria. 